\title{
WestVirginiaUniversity
}

THE RESEARCH REPOSITORY @ WVU

Graduate Theses, Dissertations, and Problem Reports

2014

\section{Copperheads and Blacksnakes: Divided Loyalty in Eastern Pennsylvania}

Chuck Welsko

Follow this and additional works at: https://researchrepository.wvu.edu/etd

\section{Recommended Citation}

Welsko, Chuck, "Copperheads and Blacksnakes: Divided Loyalty in Eastern Pennsylvania" (2014). Graduate Theses, Dissertations, and Problem Reports. 7356.

https://researchrepository.wvu.edu/etd/7356

This Thesis is protected by copyright and/or related rights. It has been brought to you by the The Research Repository @ WVU with permission from the rights-holder(s). You are free to use this Thesis in any way that is permitted by the copyright and related rights legislation that applies to your use. For other uses you must obtain permission from the rights-holder(s) directly, unless additional rights are indicated by a Creative Commons license in the record and/ or on the work itself. This Thesis has been accepted for inclusion in WVU Graduate Theses, Dissertations, and Problem Reports collection by an authorized administrator of The Research Repository @ WVU. For more information, please contact researchrepository@mail.wvu.edu. 
Copperheads and Blacksnakes: Divided Loyalty in Eastern Pennsylvania

\author{
Chuck Welsko
}

\author{
Thesis submitted to the \\ Eberly College of Arts and Sciences \\ at West Virginia University \\ in partial fulfillment of the requirements \\ for the degree of
}

\title{
Master of Arts
}

in

History

\author{
Jason Phillips, Ph.D., Chair \\ Aaron Sheehan-Dean, Ph.D. \\ Brian Luskey, Ph.D.
}

\section{Department of History}

\section{Morgantown, West Virginia \\ 2014}

Keywords: Loyalty; Civil War; Eastern Pennsylvania;

North; political culture; Nineteenth-century America;

Copperheads; Abolitionist; print culture

Copyright 2014 Chuck Welsko 


\begin{abstract}
All rights reserved
INFORMATION TO ALL USERS

The quality of this reproduction is dependent upon the quality of the copy submitted.

In the unlikely event that the author did not send a complete manuscript and there are missing pages, these will be noted. Also, if material had to be removed, a note will indicate the deletion.
\end{abstract}

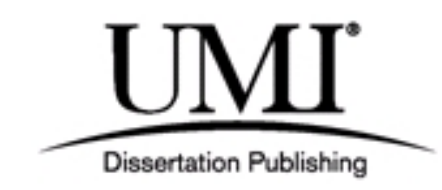

UMI 1555039

Published by ProQuest LLC (2014). Copyright in the Dissertation held by the Author.

Microform Edition (c) ProQuest LLC.

All rights reserved. This work is protected against unauthorized copying under Title 17, United States Code

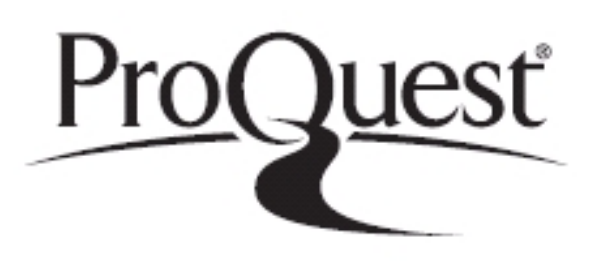

ProQuest LLC.

789 East Eisenhower Parkway

P.O. Box 1346

Ann Arbor, MI $48106-1346$ 


\section{ABSTRACT \\ Copperheads and Blacksnakes: Divided Loyalty in Eastern Pennsylvania}

\section{Chuck Welsko}

This is a study of people, politics, and rhetoric during the American Civil War. The people are eastern Pennsylvanians, the ordinary men and women from Berks, Bucks, Lehigh, and Northampton counties. The narrative traces the failure of these people to unify in the Civil War. Instead, citizens used a rhetoric of loyalty to fuel the bitter divide between Democrats and Republicans. Historians have studied the concept of loyalty extensively in the past, but only with the purpose of identifying which political or ethnic subgroups of the population were "loyal." Copperheads and Blacksnakes moves beyond the issue of who and focuses rather on the how of loyalty: the ways in which individuals - soldiers, civilians, newspaper editors - constructed notions of loyalty and used those conceptions in political discourse.

The results of such a study are dramatically different than previous scholarship. Eastern Pennsylvanians' added their definitions of loyalty to an established political culture. At the start of the war, Democrats and Republicans invoked sentiments of antipartisanship to form a common, singular sense of unity. Within weeks though, that appeal for unity and nonpartisanship faltered, first amongst newspaper editors, then amongst local residents as the Union suffered military defeats, national elections approached, and the Lincoln Administration adjusted Federal policy (with the advent of taxes, conscription, and emancipation) to crush the Confederacy. Political partisans in eastern Pennsylvania came to view their opponents disloyal to the nation, exaggerating the pre-war divisions and partisanship that dominated American politics. Citizens used loyalty to advance the interests of one party, one part of the population, that they believed was both virtuous and capable of restoring the fragmented American nation. As a result, the Civil War generated a period where derisive political rhetoric gained legitimacy as eastern Pennsylvanians envisioned their 'disloyal' political opponents as threats to the nation, ushering in an intensified and more deeply divided polity. 


\section{TABLE OF CONTENTS}

I. Introduction, Pages 1-12

II. Unity Unfulfilled: The Wartime Construction of Loyalty in Eastern Pennsylvania, 1861-1862, Pages 13-44

III. Dangerous Divisions: Loyalty and the Crisis of Democracy, 1863-1864, Pages 45-80

IV. Conclusion: Anxiety Vanquished?, 81-88

V. Bibliography, Pages 88-94 


\section{Introduction}

On March 26 and April 2, 1863, an article titled "Copperheads vs. Blacksnakes" appeared in both the Easton Argus and Easton Sentinel, two Democratic newspapers in the city of Easton, Pennsylvania. William Hutter and Daniel H. Neiman, the respective editors of both papers responded to an attack from J. P. Hetrich, the editor and proprietor of the Northampton County Journal, a Republican paper published within the same city limits. On March 4, Hetrich wrote that "It cannot be denied that an analogy between this loathsome creature [copperhead snakes] and the mean, sneaking politicians who are now distracting the Northern mind with cries of peace is quite striking," because like the snake, Democrats were "venomous" to the Union war effort. ${ }^{1}$ In response, Neiman and Hutter proudly proclaimed their support for the term Copperhead, a nickname often associated with the anti-war, anti-Lincoln faction of the Civil War Democratic Party. Their article noted that the "copperhead" was native to the United States and was a "fearless, independent" creature that was both "brave... and therefore naturally tolerant, harmless, and passive," unless it is assailed, which would prove fatal to their foe. On the other hand, the editors saw "the representative of the Abolitionist [Republicans]...the "blacksnake"" as "a cowardly, hissing, thieving reptile," that stole, robbed, and was worthy of destruction. ${ }^{2}$ Each editor, on both sides of the political divide substituted snakes for political parties, coupling their political opponents with the imagery of the slithering, disreputable reptile. This exchange, the constant debate between newspaper editors and later amongst other residents of eastern Pennsylvania, fueled the debate over loyalty that pervaded the North during the American Civil War. The constant attempts by eastern Pennsylvanians in Berks, Bucks, Lehigh, and Northampton Counties to paint their political opponents as disloyal threats to the nation created a

\footnotetext{
${ }^{1}$ Northampton County Journal, March 4, 1863.

${ }^{2}$ Easton Argus, April 2, 1863; Easton Sentinel, March 26, 1863.
} 
serious crisis in northern politics, which merits more attention from historians of the Civil War

era.

These four counties, located north and northwest of Philadelphia, partially alongside the

Delaware River, and in the shadows of the Appalachian Mountains offer an excellent place to

study loyalty because they were fairly typical for nineteenth century America. Berks, Bucks,

Lehigh, and Northampton were rural counties. They possessed some light manufacturing,

predominantly in the iron and coal industries, and market economies, but most residents toiled in

the fields. As a result, each county possessed a limited number of urban centers: Reading (Berks

County), Doylestown (Bucks County), Allentown (Lehigh County), and Bethlehem and Easton

(Northampton County), while most men and women remained in small villages or towns.

${ }^{1}$ At the time of the Civil War, after roughly two centuries of settlement by Dutch, Swedish, and predominately German settlers, the regional population had grown from a few hundred to roughly 94,000 residents in Berks County, 63,000 residing in Bucks County, 43,000 throughout Lehigh County, and another 47,000 in Northampton County. ${ }^{2}$

\footnotetext{
${ }^{11}$ W. W. H. Davis, The History of Bucks County, Pennsylvania, from the Discovery of the Delaware to the Present Time, (Doylestown, PA: Democrat Book and Job Office Print, 1876), 23, 444, 712; William J. Heller, History of Northampton County[Pennsylvania] and the Grand Valley of the Lehigh, (New York: The American Historical Society, 1920), 42, 52-3, 149, 161, 269; Morton L. Montgomery, History of Berks County in Pennsylvania, (Philadelphia: Everts, Peck \& Richards, 1886), 3, 5-6, 7, 11-2, 24-5; Daniel I. Rupp, History of Northampton, Lehigh, Monroe, Carbon, and Schuylkill Counties: Containing a Brief History of the First Settlers; Topography of Townships; Notices of Leading Events, Incidents, and Interesting Facts in the Early History of these Counties, (Harrisburg, PA: Hickok and Cantine, Printers and Binders, 1845), 1-9, 12-3, 25, 111.

${ }^{2}$ These figures are approximations, because from the sources there seemed are some minor discrepancies. In the Berks \& Schuylkill Journal, the population figures for Berks, Bucks, Lehigh, and Northampton counties respectively are $94,043,63,803,43,932,47,775$. Heller on the other noted that the population of Northampton County was 47,900 in 1861 and Montgomery positioned the populations of Berks as 93,818, Bucks at 63, 578, and Lehigh at 43, 753 in his work. The even estimates on my part are an attempt to paint a rough picture of the region's population, bringing together the figures from these different sources. Berks \& Schuylkill Journal, November 17, 1860; Heller, History of Northampton County, 161; Montgomery, History of Berks County, 647. Additionally, Berks, Lehigh, and Northampton counties each contained one German paper during the Civil War. I was unable however to read these papers, due in large part to a dearth of my abilities in German as well as the fact that some papers were unattainable. However, each of these papers, as evidenced from the pro-Republican papers in eastern Pennsylvania identify the
} 
Eastern Pennsylvania represented the agrarian, (but also slightly urban) character of Civil War America, but it also presented a unique political background as well. Eastern Pennsylvanians, and Keystone Staters in general, possessed a long affiliation with conservative political traditions. After the American Revolution, the Pennsylvania constitution favored a weak government, which shunned the federal centralization of power. ${ }^{3}$ A prime example in Northampton and Bucks counties, Jacob Fries organized four hundred men to demand the release of several men arrested for resisting a 1798 tax. Fries wanted to return the men for local, not federal trials, but was branded a traitor by the government, and stopped by a militia raised from Lancaster County. ${ }^{4}$ Reflecting this strong conservative tradition, eastern Pennsylvania provided a solid base of support for the Democratic Party throughout much of the antebellum period. ${ }^{5}$ However, in the 1860 Presidential Election, the local voters divided between support for a Republican and Democratic candidate. Both Berks and Northampton counties remained solidly Democratic, voting almost with a two to one margin against Abraham Lincoln and the other presidential hopefuls. Most voters of Berks and Northampton supported the Democratic Fusion ticket, offering their votes to either John Breckinridge or Stephen Douglas, whichever Democrat they felt had the better chance of securing the Presidency. Lehigh and Bucks County, on the other hand, edged out victories for Abraham Lincoln. Other surrounding counties in eastern

fact that the German papers were solidly German, providing similar discussions of loyalty as their English speaking Democrat counterparts. The German papers included the Reading Adler from Berks County, the Republikaner in Lehigh County (which despite its name was a Democratic papers) and the Correspondent and Demokrat in Northampton County. Furthermore, David L. Valuska identified Berks, Lehigh, and Northampton Counties as "Dutch Counties" during the Civil War. David L. Valuska and Christian Keller, Damn Dutch: Pennsylvania Germans at Gettysburg, (Mechanicsburg, PA: Stackpole Books, 2010), 47.

${ }^{3}$ Ronald P. Formisano, For the People: American Populist Movements from the Revolution to the 1850s, (Chapel Hill: University of North Carolina Press, 2008), 21-2; Arnold Shankman, The Pennsylvania Antiwar Movement, 1861-1865, (Rutherford, NJ: Farleigh Dickinson University Press, 1980), 16.

${ }^{4}$ Formisano, For the People, 58; Heller, History of Northampton County, 131-42; Rupp, History of Northampton, Lehigh, Monroe, Carbon, and Schuylkill Counties, 116.

${ }^{5}$ Heller, History of Northampton County, 241-6; Montgomery, History of Berks County, 476; Shankman, The Pennsylvania Antiwar Movement, 16. 
Pennsylvania mirrored this divide, yet by 1864 , each county voted strongly for the Democratic candidate George McClellan. ${ }^{6}$

The rhetoric of loyalty produced by Democrats and Republicans dominated political discourse throughout the war. For a brief period at the onset of the Civil War, residents of eastern Pennsylvania presented themselves as united behind nationalism and antipartisanship in their course to crush the Confederacy and restore the American Union. They portrayed the North as loyal and the Confederacy, along with anyone who supported them, as disloyal. But Eastern Pennsylvanians' enthusiasm for unity reflected only a façade built on traditional political rhetoric that supported the ideal of antipartisanship. In essence, eastern Pennsylvanians mirrored the wider political culture of the nineteenth century. Antipartisan rhetoric dominated much of the early American political system when Federalists and Democratic-Republicans positioned themselves as opposed to party politics in the hope of attracting voters and legitimizing their party. ${ }^{7}$ While local residents adopted a similar language that eschewed party at the start of the war, their sincerity was questionable. As the war progressed, battle defeats mounted, and public policy (especially in terms of emancipation and conscription) changed, Democrats and Republicans quickly painted their partisan opponents as disloyal elements working against the restoration of the nation.

This transition to antagonistic uses of loyalty began first with local newspaper editors but slowly filtered into the correspondences of local residents. Such a transition also represented

\footnotetext{
${ }^{6}$ Shankman, The Pennsylvania Antiwar Movement, 18, 135-6, 199-200; Bucks County Intelligencer, November 13, 1860, October 27, 1863; Doylestown Democrat, October 27, 1863; Easton Sentinel, November 15, 1860; Reading Gazette and Democrat, October 17, 1863.

${ }^{7}$ Ronald Formisano, The Transformation of Political Culture: Massachusetts Parties, 1790s-1840s, (New York: Oxford University Press, 1983), especially pages 11-4 as well as chapter 1 through 4. Formisano's focus on antipartisanship, connections to the Revolutionary generation, and attempts to delegitimize political opponents mostly during the first two-party system proved instrumental in helping flesh out the contours of my work.
} 
some of the broader contours of early American political culture, most noticeable the foundational premise of a two-party system. As the start of the Civil War, eastern Pennsylvanians cast the Confederacy as disloyal, maintaining the two-party framework, but as opinions over the conduct of the war diverged in the North, regional partisans translated the rhetoric of disloyalty into their interior political workings, casting political opponents as disloyal. While these actions retained some elements of antebellum political culture, we should not assume that the language of loyalty and the Civil War simply replicated the rhetoric of the preceding decades. Certainly, eastern Pennsylvania offered many similarities, but they also offered their fair share of differences. The context of the Civil War is the most significant departure from the antebellum period. The severing of the nation, the possibility of destruction (physical and national), and the sheer scale of the war presented Americans with a completely different experience from the political conflicts of the early 1800s. Within this new context, a tangible moment appeared where the language of national loyalty took on a new, more threatening meaning. The political behavior of eastern Pennsylvanians revealed how the Civil War nearly destroyed the experiment of democracy in the North. As a side effect of this intensified political rhetoric, eastern Pennsylvanians came to see that national destruction could only come from the election of their political opponents. It is important to clarify though, despite the professions and beliefs of Civil War era partisans, neither party in eastern Pennsylvania endeavored to destroy the nation. They were at odds on how to fix it, which prompted Republicans and Democrats alike to fall back on their traditional political learningsdelegitimizing their opponents. Or in this sense, they labeled their opponents disloyal. ${ }^{8}$

\footnotetext{
${ }^{8}$ Formisano, The Transformation of Political Culture, 108; David Waldstreicher, In The Midst of Perpetual Fetes: The Making of American Nationalism, 1776-1820, (Chapel Hill: University of North Carolina Press, 1997).
} 
That context, the potential destructive ability of the conflict, created a unique outcome of the loyalty debate: a crisis of democracy. Although contemporaries failed to use such a phrase, it serves as a tidy way to encapsulate their sentiments. They certainly expressed concern over the perils of the Civil War. Specifically, as the war pressed on and changed (including the expansion of federal power, emancipation, conscription), local residents began to see their political opponents as legitimate threats to their nation. Democrats and Republicans eventually saw the democratic process as not only the means of saving the nation (through the election of their party) but also as holding the potential for its destruction (through the election of their opponents).

Historians have studied loyalty in the past, but have spent most of that time retrospectively trying to prove the loyalty of a specific political or ethnic subgroup during the war. Frank Klement's scholarship typified this line of historiography; he focused on proving that Copperheads, the anti-war, anti-Lincoln branch of the Democrat Party, were actually loyal Americans during the Civil War. This interpretation countered preceding historians who argued that Northern dissidents during the war were disloyal and traitorous elements intentionally subverting the Union war effort. ${ }^{9}$ But such scholarship, while informative, has had a distracting effect that remains unresolved. Other historians, such as Arnold Shankman, Grace Palladino, and Robert Sandow, followed Klement's lead in their attempts to disprove the label of disloyalty attached to various segments of Pennsylvania's population. While all three studied loyalty within the Keystone State, again they mostly tried to prove the loyalty of the state's dissenting elements,

\footnotetext{
${ }^{9}$ Frank L. Klement, The Copperheads in the Middle West, (Chicago: The University of Chicago Press, 1960), 134$155,182,205,239-41$. Klement specifically countered the arguments of historians such as Wood Gray's The Hidden Civil War: The Story of the Copperheads and George Fort Milton's Abraham Lincoln and the Fifth Column.
} 
whether they were Irish miners or Appalachian farmers. ${ }^{10}$ Each scholar provided illuminating works, which greatly improved our knowledge of wartime dissenters, but failed to push the use of loyalty beyond a narrow, binary approach that retrospectively argued for the loyalty of specific groups during the war years. The goal should not be to prove who was loyal — in fact it is impossible to prove because both parties stressed their own loyalty at the expense of their political opponents. It was common practice throughout antebellum and Civil War America to legitimize one's own party while delegitimizing their opponents. Instead, historians should focus on how ordinary individuals conceptualized and used loyalty in their daily lives.

In order to understand the how of loyalty, there are a number of other 'historiographies' at play within this text, predominately focused on nineteenth century political culture. To move beyond an either-or paradigm of loyalty, I borrowed extensively from the methodology and findings of recent historians of nineteenth-century political culture such as Elizabeth Varon, Mark Neely, Adam I. P. Smith, Melinda Lawson, David Waldstreicher, Ronald Formisano, and others. Varon offered a conceptual framework in her examination of how nineteenth century

\footnotetext{
${ }^{10}$ Shankman, Palladino, and Sandow each studied Pennsylvania, but provided different arguments about the state. Shankman broadly compared the intensity of Pennsylvania's anti-war movement to that of the Midwest and New York. Like Klement, Shankman argued that Copperheads were loyal and posed little threat to the Union war effort. Palladino looked at Carbon, Luzern, and Schuylkill Counties in Pennsylvania (the coal mining region of Pennsylvania) and argued that the predominately German and Irish miners in the region acted loyally during the war. The miners protested for increased wages as inflation occurred during the war and wartime coal profits rose. At roughly the same time, these three counties resisted conscription as well. Republicans and mine owners interpreted this as the same resistance to the war, but Palladino argued that there were separate issues and that the miners acted loyalty because they wanted a fair increase in pay and were not working with the South to overthrow the North, as Republicans accused. Lastly, Sandow argued that resistance in north-central Pennsylvania, the Appalachian lumber region, resisted the war due to pre-war economic conditions. Prior to the war, outside companies took over the lumber industries that farmers relied on to support their finances. When the courts and violence failed to return control of the lumber industry to miners, the farmers and people of north-central Pennsylvania distrusted outside intervention. During the war, this prompted resistance to the Republican administration and its centralization of federal power. Sandow concluded that these Pennsylvanians were loyal although they resisted the Lincoln Administration, because they did not support the Confederacy, but resisted wartime policies out of an extension of pre-war conditions. Grace Palladino, Another Civil War: Labor, Capital, and the State in the Anthracite Regions of Pennsylvania, 1840-1868, (Urbana: University of Illinois Press, 1990); Robert Sandow, Deserter Country: Civil War Opposition in the Pennsylvania Appalachians, (New York: Fordham University Press, 2009); Shankman, The Pennsylvania Antiwar Movement.
} 
newspaper editors and politicians used the term "disunion." She offered historians a means to conceptualize how Americans before and during the Civil War deployed a specific phrase and its cultural resonances. ${ }^{11}$ Smith and Lawson produced foundational studies of wartime loyaltyactually defining how Northerners saw loyalty, not just whether or not certain segments of the population were loyal. Smith argued that members of the Union Party (Republicans and War Democrats bound together in the hopes of crushing the Confederacy) placed unconditional, nonpartisan support of the government at the heart of their definition of loyalty. ${ }^{12}$ In a different vein, Lawson urged that definitions of wartime loyalty built on the antebellum connections between nation and party, in which both Democrats and Republicans viewed partisan affiliation as a key component of an individual's loyalty. ${ }^{13}$ Lawson and Smith demonstrated the connectivity between Civil War politics and the conceptualization of loyalty. In short, participants conflated partisan loyalty as an expression of national loyalty or disloyalty.

Waldstreicher, Formisano, and Neely proved instrumental in forming a bare bones construction of political culture in the decades leading to the Civil War. Formisano (along with Neely and Adam I. P. Smith) demonstrated that antipartisanship, connections to the Founding Fathers and the Constitution, as well as attempts to legitimize one party, were key constructs of antebellum political discourse. ${ }^{14}$ Waldstreicher, through his own publications and edited volumes, highlighted a broader range of activities, events such as parades, toasts at receptions,

\footnotetext{
${ }^{11}$ Elizabeth Varon, Disunion!: The Coming of the American Civil War, 1789-1859, (Chapel Hill: The University of North Carolina Press, 2008). Varon argued that nineteenth century Americans used "disunion" in five specific ways: as a Prophecy, Threat, Accusation, Process, or Program.

${ }^{12}$ Adam I. P. Smith, No Party Now: Politics in the Civil War North, (Oxford: Oxford University Press, 2006).

${ }^{13}$ Melinda Lawson, Patriot Fires: Forging a New American Nationalism in the Civil War North, (Lawrence, Kansas: University of Kansas Press, 2002), 10-1, 65-97.

${ }^{14}$ Formisano, The Transformation of Political Culture, 14, 27, 30; Neely, The Union Divided: Party Conflict in the Civil War North, (Cambridge: Harvard University Press, 2002), 8, 13, 27; Smith, No Party Now, 5, 12, 15, 68-73.
} 
and gift giving that held political meaning. ${ }^{15}$ Such examples allowed me to realize how other events (like parades or flag presentations) embedded loyalty into the daily political life of eastern Pennsylvania.

Neely also added depth to my understanding of a two-party system that hampered the Union war effort. ${ }^{16}$ The old argument_ proposed by David Potter, established by Eric McKitrick, and condoned by recent historians - was that the North's two-party system conferred great advantages on the Union war effort. That system served as a means for Northerners to channel their frustrations, blow off steam, but also hone their focus. In comparison to the Confederacy, which lacked an established opponent to the dominance of the Democratic Party, their system lacked the ability to organize the energies of their people and contain their disagreements. ${ }^{17}$ Neely challenged that traditional line of thought, arguing that the disagreement and divisions caused by divergences of opinions amongst Northern politicians actually distracted the Union. Nonetheless, I disagree with some of Neely's assertion that the two-party system was defunct in the years leading up to the Civil War. While certainly the collapse of the Whig Party in the 1850s gave Democrats considerable influence, a string of smaller second parties (and even some third tier ones) rose and fell during the decade. ${ }^{18}$ This is true, yet, I found that eastern Pennsylvanians relied on the structure of a two-party system, a framework engraved in them throughout the early parts of American history. They used the contours of a two-party system to

\footnotetext{
${ }^{15}$ Waldstreicher, In The Midst of Perpetual Fetes, particularly chapter 1.

${ }^{16}$ Neely, The Union Divided, 3-4, 179-89.

${ }^{17}$ Eric McKitrick, "Party Politics and the Union and Confederate War Efforts," in William Nisbet Chambers and Walter Dean Burnham, eds., The American Party System: Stages of Development, (New York: Oxford University Press, 1967); James McPherson, Battle Cry of Freedom: The Civil War Era, (New York: Oxford University Press, 1988), 690; Phillip Shaw Paludan, A People's Contest: The Union \& Civil War, 1861-1865, $2^{\text {nd }}$ Edition, (Lawrence, Kansas: University of Kansas, 1996), 89. 378. Neely and Adam I. P. Smith have gone to lengths to challenge this idea that the two-party system helped the Union War effort, to which I also add my voice. Neely, The Union Divided, especially chapter 7; Smith, No Party Now, 154-61.

${ }^{18}$ Neely, The Union Divided, 7-8, 33-4, 174.
} 
form and implement their definitions of loyalty. ${ }^{19}$ The result of such usage was that eastern Pennsylvanians hardened political divisions in the region, providing the foundations of a bitter division that permeated wartime and post-war politics in the region.

Tangentially connected to the discussion of political culture, my research also touches upon another aspect of nineteenth-century United States historiography: how did people explain what it meant to be an American. Much of the recent literature put forth by American historians discussed how individuals envisioned their status as Americans. These examinations include a gambit of different works, such as Ann Fabian's focus on phrenology and scientific racism, Kariann Yokta's attention to how early Americans mirrored British customs and styles, but attempted to break from those practices, and participation in reform movements as Bruce Dorsey demonstrated. Regardless of their differences, they all constituted avenues of defining what it meant to be an American. ${ }^{20}$ The contentious use of loyalty in eastern Pennsylvania offered another arena in which Americans argued about who belonged in or out of American society. Their use of loyalty, in which one party asserted who should have political control over the Union war effort, also made the case for who should or should not be deemed worth of American liberties.

\footnotetext{
${ }^{19}$ I adopted this idea from Formisano's The Transformation of Political Culture when he noted that "Both sides[ Federalists and Republicans], furthermore, tried to stigmatize their opponents as illegitimate" through a variety of nicknames and accusations. Republicans and Democrats implemented a similar line of discourse during the Civil War. In essence, Formisano's comment on America's early political system helped framed the idea that in order for one party to present themselves as legitimate (or in my case loyal), they needed something illegitimate (or disloyal). Formisano, The Transformation of Political Culture, 108.

${ }^{20}$ To list but a few of the works that revolve, on some level, about the meaning of being an American in the nineteenth century: Bruce Dorsey, Reforming Men \& Women: Gender in the Antebellum City, (Ithaca: Cornell University Press, 2002); Anne Fabian, The Skull Collectors: Race, Science, and America's Unburied Dead, (Chicago: University of Chicago Press, 2010), Karl Jacoby, Shadows at Dawn: An Apache Massacre and the Violence of History, (New York: Penguin Books, 2008); David Jaffee, A Nation of New Goods: The Material Culture of Early America, (Philadelphia: University of Pennsylvania Press, 2010); Stephen Kantrowitz, More Than Freedom: Fighting for Black Citizenship in a White Republic, 1829-1889, (New York: The Penguin Press, 2012); Varon, Disunion; Kariann Akemi Yokota, Unbecoming British: How Revolutionary America Became a Postcolonial Nation, (Oxford: Oxford University Press, 2011).
} 
With this literature in mind, there are really two broad conclusions from my study of loyalty in Berks, Bucks, Lehigh, and Northampton Counties. The first is predominantly conceptual, in that I advocate a different approach to the topic of loyalty in Civil War scholarship. Historians have largely treated loyalty within a binary framework, in that individuals could only be loyal or disloyal and the historians' job is to identify and categorize participants. Such a treatment of the concept in a historical sense greatly diminishes the complexity of loyalty. Loyalty was a lens through which men and women viewed the Civil War. Republicans and Democrats alike asserted their loyalty while they denounced that of their opponents. Therefore, historians should refrain from casting one political group (or ethnicity, gender, race or any particular means of classification) as strictly loyal and the other disloyal. Instead, they should focus on how people's definitions of loyalty influenced their experience with the war itself.

This reconceptualization of loyalty leads directly into the next major point of my research: the meaning and use of loyalty in partisan discourse of eastern Pennsylvania. Two iterations of loyalty ran through the region between 1861 and 1865. In the first year and a half of the war, local individuals presented loyalty as a unifying principle that aligned Northerners as loyal and the Confederacy as disloyal. That division was not perfect. Early in the war, newspaper editors implemented the concept of loyalty as a political tool to support their vision and strengthen their party. Democratic and Republican editors by May of 1861 began to accuse their opponents of disloyalty, while they simultaneously affirmed their loyalty. Republican editors claimed they desired perfect support of all wartime policies, while Democratic editors proposed a version of loyalty that adhered strictly to the Constitution, returning the nation to a status quo antebellum. As the war grew longer, the Lincoln Administration took harder steps to ensure the Union's victory. This included the restriction of civil liberties, the introduction of conscription, 
and most importantly, the emancipation of Southern slaves. Each of these actions, undertaken by Union officials to help win the war, served as evidence of disloyalty to Democratic editors in eastern Pennsylvania. In turn, they increasingly criticized the Lincoln Administration. This criticism proved for their Republican counterparts that local Democrats were disloyal. Eventually the language of derisive loyalty seeped into the discourse of ordinary men and women throughout the region around the fall of 1862 . Soldiers, civilians, and editors began privileging partisan affiliation as the main indicator of loyalty. The result was a crisis for democracy in the elections of 1863 and 1864, where eastern Pennsylvanians came to view the election of their partisan challengers, what they saw as disloyal elements of society, as the threat to the nation, its restoration, and durability.

The findings of this project are suggestive in scope. My examination of Berks, Bucks, Lehigh, and Northampton Counties does not represent the entirety of the North, the Border States, and of course the eleven southern states that joined the Confederacy. However, I believe that a study focused more on the what and how of loyalty, rather than the who, begins to reorient and complicate our understanding of the Civil War. The issue of wartime loyalty permeated the daily lives of eastern Pennsylvanians and shaped their experience with the war. They built off their established understandings of antebellum political culture, but their use of loyalty also produced a break from the past. Within the volatile context of the Civil War, men and women's use of loyalty offered a dire moment for the future of the nation, one that prompted intense debate and division about who had the nation's best interests in mind. Understanding the use of loyalty as a complicated and intricate concept that individuals implemented to understand the sectional conflict helps us understand how dangerous the Civil War was to all its participants, North and South. 


\section{Chapter One}

\section{Unity Unfulfilled: The Wartime Construction of Loyalty in Eastern Pennsylvania, 1861-1862}

On September 19, 1861, Lewis Gordon, the proprietor of the pro-Republican Easton Free Press published part of a letter sent to his office from a local volunteer, Captain J. J. Horn of the 12th Pennsylvanian Reserve Corps. Camped near Washington D. C., Horn penned a typical letter that described camp life, the drills of the Union Army, as well as the prospects of a Confederate attack against the Union capital, which he deemed unlikely. At the end of the letter though, Horn combined a discussion of the war, politics, and loyalty into one scintillating paragraph. In his conclusion, Horn rebuked "northern sympathizers," those Democrats he believed supported the Confederacy for their recent countywide meeting on August 19. Reflecting on the Democratic meeting in his native Northampton County that ended in a violent clash between local residents, Horn believed "there are still worse traitors [in Easton] than here" at the front. If "the men who composed that meeting...elect" a county or state ticket "I shall class my own native county in the same catalogue with secession counties here [in Virginia]." Horn positioned local Democrats, the "northern sympathizers" who opposed the war, as a dangerous entity, equal in disloyalty, and more loathsome than the actual Confederates who seceded and took up arms against the United States. In the end, Horn hoped that his home county would "elect to office good Union men without distinction of party" but no "northern sympathizer," because it would serve as a disgrace to both the county and the Union. ${ }^{23}$

\footnotetext{
${ }^{23}$ At the Democratic County meeting on August 19, 1861, Northampton County Democrats passed resolutions that blamed Republicans for the war, called for peace, and affirmed the loyalty of the Democratic Party. After a speech by the local congressional representative, Phillip Johnson, a fight broke out between soldiers and meeting organizers. After the fight, a pro-Union mob marched through Easton with an image of Johnson in effigy and damaged two Democratic printing presses. That evening's events appear again in this text, but warrant mention here, because they prompted Horn's letter and concern about the loyalty of his home county. Easton Free Press, August 22, 1861 and September 19, 1861; Northampton County Journal, August 21, 1861; Reading Democrat and Gazette,
} 
Horn's letter and its appearance in the Free Press was part of the debate over loyalty that transpired throughout Berks, Bucks, Lehigh, and Northampton counties in eastern Pennsylvania during the Civil War. The publication of Horn's letter in a local Republican paper illuminated three key aspects of the conflict over loyalty. First, Horn's desire for the election of a nonpartisan "Union" candidate reflected a desire amongst the region's soldiers and civilians for a unified, apolitical vision of the war that only sought to restore the Union and the Constitution. For the first sixteen months of the Civil War, this apolitical, unifying sentiment dominated the sentiments of most, but not all, individuals in eastern Pennsylvania. Second, Horn's animosity towards Democrats in Northampton County, demonstrated that the interjection of politics into the discussion of loyalty fragmented any impetus for unity. Lastly, the appearance of Horn's letter in the Free Press highlighted the importance of newspapers as a medium in the political debate over loyalty. Newspapers and their editors served as mouthpieces for local political parties, facilitated the transmission of information and conducted much of the debate about loyalty between political parties and later local residents. ${ }^{24}$ From the onset of the conflict, soldiers and civilians in eastern Pennsylvania cast the war, in all its aspects, as part of a narrative about loyalty in the face of rebellion and secession. Loyalty however, was a broad concept, one malleable and open to interpretation for local residents. Early in the war, two divergent visions of loyalty developed, one amongst the citizenry who sought to build unity and another amongst newspaper editors that generated division. In this light, citizens of these counties manifested two components of antebellum political culture in their discourse over loyalty. The first was an

\footnotetext{
August 24, 1861; The Pennsylvania Antiwar Movement, 1861-1865, (Rutherford, NJ: Farleigh Dickinson University Press, 1980), 73.

${ }^{24}$ Adam I.P. Smith and Jeffrey Pasley both noted the importance of newspapers to the discussion andspread of political ideas. Smith noted that in nineteenth century and Civil War America, the circulations of newspapers were small, but that most towns or cities had one paper for each of the two main parties, while Pasley noted that in the Early Republic, newspapers served as the only place where "ideas, attitudes, policies, and candidates" came together "under the party label." Pasley, "The Cheese and the Words," 41; Smith, No Party Now, 79.
} 
antipatisan distrust of political parties, especially in the face of secession. On the popular level, amongst soldiers and civilians, antipartisan unity found a stronger foundation than amongst newspaper editors. Partisan mouthpieces, although they preached unity at the onset of the conflict, by May 1861, slipped back into the second continuation of political culture, which was bitter criticism of their opponents, couched in the language of loyalty. By the fall of 1862 , soldiers and civilians joined in a contentious use of loyalty.

Against this backdrop, the focus of my argument is to move our analysis away from trying to determine who was loyal during the war and instead explain how ordinary individuals envisioned loyalty. To accomplish this I aim to demonstrate three key elements of the loyalty debates in eastern Pennsylvania: the ways in which ordinary individuals used and understood loyalty during the war, how newspaper editors politicized and intensified the debate over loyalty, and how those virulent discussions of loyalty generated a crisis for American democracy. Loyalty was more than just a state of being for Americans during the Civil War; it was a concept and lens through which individuals viewed wartime politics. The period between April 1861 and the fall of 1862 was the first stage in the construction of loyalty, where that concept began as a unifying principle for eastern Pennsylvanians in support of the government, but due to the incursion of politics, became derisive. This first stage of loyalty is crucial to understand how ordinary citizens of both political parties, used the concept differently throughout the conflict. Because at the start there was unity, but as the war continued and transformed into a "hard war," including emancipation as well as the curtailment of civil liberties, the desire for unity fell apart. The unfulfilled push for nonpartisan unity created a crisis for democracy, where in the later parts of the war, individuals saw their political opponents as a threat to the nation. 
In order to understand how the effort to build unity actually drove people apart, we must turn our attention to the use of loyalty by ordinary civilians and soldiers from Berks, Bucks, Lehigh, and Northampton counties. During the early stages of the Civil War, the residents of eastern Pennsylvania produced a version of loyalty, devoid of politics, national in scope, but sectional in practice, that urged a united war effort to crush the Confederacy. The response of the local citizenry who raised troops, donated money, and offered supplies to support the war effort in the immediate aftermath of the attack on Fort Sumter on April 12, 1861, mirrored the traditional narrative of the North's response to the onset of the Civil War. Historians such as James McPherson, Philip Shaw Paludan, and Allen Guezlo in their syntheses of the Civil War era presented the start of the war in the North as a moment of unity when Northerners came together as a wave of patriotism swept over the country. ${ }^{25}$ In the words of Thomas Jackson, an English-born abolitionist from Reading with a fiery disposition, this unanimity did occur in eastern Pennsylvania."[W]hen the rebellion first broke out" he wrote his cousin in England, "the northern people were united in the determination to support the national government and put [the rebellion] down, and for a time, party lines seemed to be entirely forgotten." ${ }^{26}$ Jackson revealed a moment at the onset of the war where eastern Pennsylvanians came together and rallied around a singular, nonpolitical version of loyalty. Three types of events-War Meetings, the

\footnotetext{
${ }^{25}$ There are of course some works, like Scott Nelson and Carol Sheriff's A People at War, that mention the divided nature of the conflict, but the general interpretative bent has been to position the start of the Civil War as a moment of unification for the North, while downplaying the differences that existed. Allen C. Guelzo, Fateful Lightning: A New History of the Civil War and Reconstruction, (New York: Oxford University Press, 2012), 138-40; McPherson, Battle Cry of Freedom, 274-5; James McPherson, For Cause and Comrades: Why Men Fought in the Civil War, (New York: Oxford University Press, 1998), 15-7; Paludan, A People's Contest, 6-15; Carol Reardon, "“We are all in this war': the 148th Pennsylvania and home front dissension in Centre County during the Civil War." In Union Soldiers and the Northern Home Front: Wartime Experience, Postwar Adjustments, Edited by Cimbala, Paul A. and Randall Miller, (New York: Fordham University Press, 2002), 4.

${ }^{26}$ Thomas. Jackson, Letters, 1862-1874, Historic Society of Berks County, Reading, Pennsylvania, August 20, 1863 to cousin.
} 
participation of women, and the defense of a locality's loyalty—between 1861 and early 1862 illuminate how common men and women attempted to construct that nonpartisan version loyalty.

The chronology here is important, because at the beginning of the war, civilians, soldiers, and newspaper editors all professed unity, yet those statements unraveled at different speeds. By the middle of May 1861, newspaper editors began to criticize and hint at the disloyalty of their opponents. Soldiers and civilians, with a few exceptions, maintained the rhetoric of unity and nonpartisanship until the fall of 1862 . Both actions, though editors and ordinary civilians diverged from one another early in the war, conformed to traditional partisan culture. Newspaper editors maintained the structure of debate in a two-party system, while local residents called upon unity and the language of nonpartisanship (including connections to the Revolutionary generation and Constitution). This divergence however calls into question the depth of nonpartisan sentiments amongst eastern Pennsylvanians. The best way to understand this process is to explore how civilians used loyalty alongside the use of soldiers and newspaper editors.

Eastern Pennsylvanians hosted large, nonpartisan war meetings twice between the spring of 1861 and the fall of 1862: at the immediate onset of the war in April 1861 and in the summer of 1862 after the Army of the Potomac failed to capture Richmond during the Seven Days Battles. ${ }^{27}$ Local organizers hosted these meetings often, but not exclusively, in the larger urban centers of each county, and represented an opportunity to bring the people of the region together for a display of support, irrespective of political party, for the Union war effort. Regardless of when or where local officials held these meetings, they operated under a similar system. A call went out in the local newspapers that urged residents to attend the meeting. During that meeting,

${ }^{27}$ Berks \& Schuylkill Journal, April 20, 1861, July 12, 1862; Easton Sentinel, July 24, 1862; Easton Free Press, April 18, 1861; Northampton County Journal, April 17, 1861, July 30, 1862; Reading Gazette and Democrat, August 30, 1862. 
prominent men, such as political office holders, newspaper editors, or businessmen, elected an executive panel that crafted resolutions to indicate the people's support for their soldiers, the Union, and the war. Each meeting declared a sentiment akin to that of the residents of Reading in April 1861, who proclaimed "an undying devotion to the Government and Constitution of the United States." 28 In addition to their professions of nonpartisan, patriotic support for the government, each of these meetings appealed directly to the legacy of the Revolutionary generation. Whether the resolutions passed at these meetings called on local residents to preserve, "the previous free institutions handed down to us from our Revolutionary sires" or fight in memory of the blood shed by the soldiers of the Revolution, they drew on a usable past that was apolitical and attempted to pull local residents together in support of the Union. ${ }^{29}$

Mass war meetings held in Easton, Reading, Allentown, and Doylestown certainly brought out a wide range of spectators, but a careful examination of the individuals elected to run these meetings reveal that it was predominately a male dominated activity. The list of the officers elected to coordinate these meetings came from a wide selection of persons with local distinction, either politically, economically, or legally. While men dominated the organization and conduct of these meetings, women most certainly attended as well, though their presence in the loyalty debates often took a less outspoken mode. One of the most common ways that women participated in the discussion of national loyalty was through the presentation of flags to soldiers in the field. Flags were another example of a useable past serving as a physical link between home and the front. A specific instance of the presentation of a flag occurred in November 1862. Stationed at Maryland Heights, Virginia, near Harpers Ferry, Captain John

\footnotetext{
${ }^{28}$ Berks \& Schuylkill Journal, April 20, 1861.

${ }^{29}$ Berks \& Schuylkill Journal, April 20, 1861; Easton Free Press, April 18, 1861; Easton Sentinel, July 24, 1862 ; Northampton County Journal, April 17, 1861 and July 30, 1862; Reading Gazette and Democrat, August 30, 1862.
} 
Dillinger from Lehigh County wrote a letter home to thank two women for their generous donation to him and his unit. The women, Mary Samuels and Emma Knauss, gave Dillinger a pair of handmade gloves, which he was thankful for because it was "very cold here and to handle a musket in the cold, it is a hard thing." Samuels and Knauss also provided Dillinger's company with a flag, which he noted, "now waves on the very pole that the traitor Miles surrendered to the rebels" and hoped to bring home in May 1863 when the unit returned to eastern Pennsylvania. ${ }^{30}$ The flag Mary and Emma offered to Dillinger's unit presented an obvious connection to their expression of patriotism. They offered the flag as the embodiment of the nation, a reminder of home, and a call for a unified war effort. Much like the reflections of the nation's Revolutionary sires at war meetings, the flag served as a unifying symbol of the nation that soldiers and civilians, regardless of their political affiliation, could rally around to support and defend. Additionally, Dillinger's positioning of the flag with the reference to Dixon S. Miles, the “traitor” who surrendered Harpers Ferry in September 1861, grounded Dillinger's letter more firmly in the discussion over loyalty. ${ }^{31}$ For Dillinger, Miles' poor military strategy and his failure to maintain possession of Harpers Ferry made him a traitor, while the presentation of the flag from Samuels and Knauss, represented a loyal action, the antithesis of Miles. The fact that he referenced Miles as a traitor, lends credence to the fact that he believed that the two women offered loyal service by providing him with gloves and the unit with a flag. Women like Mary Samuels and Emma Knauss presented a unified, national connection to their soldiers in the field,

\footnotetext{
${ }^{30}$ John P. Dillinger, Letter to Mary Samuels and Emma Knauss, November 20, 1862, Lehigh Valley Heritage Museum, Allentown, Pennsylvania. Later in the war, a group of women from Easton, dropped off a flag at the door of the Easton Sentinel's office, with a note that proudly proclaimed their support for the actions and beliefs of the paper. While outside the chronology of this section, it is important to note that women made the flag and used it to express their support for the Sentinel's Democratic messages, both about politics and loyalty. The "traitor Miles" refers to Dixon Miles, who poorly handled the defense of Harper's Ferry and surrendered the arsenal in September of 1862 .

${ }^{31}$ McPherson, Battle Cry of Freedom, 538.
} 
which represented their affirmation of a version of loyalty that supported both the men in the Union Army as well as the war effort.

Women also expressed both loyalty and a desire for unity through the formation of local aid societies geared towards benefiting the local soldiers. Supporting their sons, fathers, and brothers in the field offered the women another connection to the nation as it went to war. Although small in the number of participants, many of the towns and cities across eastern Pennsylvania formed these societies to collect food, clothing, and supplies for local volunteers in the Union Army. With newspaper campaigns and festivals, such as the three-day Strawberry Festival hosted in Easton in June 1862, their goal was to collect food and clothing for local soldiers. ${ }^{32}$ Akin to the early presentations of flags, the actions of the aid societies connected their participants to the national goal of preserving the Union. The collection and donation of local supplies for volunteers in the field certainly tied together the homefront and the soldiers in the field. In doing so, it offered women another way to demonstrate loyalty because they supported their local soldiers directly. Women also used the endeavors of Aid Societies to represent their loyalty, as was the case with the town of Hatborough in the spring of 1862.

In the early part of 1862 , the veneer of unity began to crack. Located in Bucks County, the small town of Hatborough came under criticism in February and March of 1862, when a group of unspecified neighbors criticized the town of pervasive disloyalty. The defense of Hatborough by a local resident under the guise "Loyal" tied the participation of the town's male and female population together. On March 4, 1862, "Loyal" published a letter in defense of the small town in the Doylestown Democrat. In that letter, "Loyal" focused on two elements to prove

\footnotetext{
${ }^{32}$ Northampton County Journal, June 18 and 25, 1862. The Journal deemed the event a success, because the women raised approximately $\$ 250$ for local soldiers.
} 
the loyalty of the local town and vicinity: the enlistment of Hatborough's men in the Union Army and the materials offered up through the local Soldier's Aid Society. "Loyal" equated both actions as evidence of the people's loyalty, regardless of their political affiliation. For "Loyal," an individual's loyalty came from their actions that supported the war effort, regardless of gender or political distinctions. This letter and defense of Hatborough by "Loyal" demonstrated that some individuals in early 1862 presented the issue of loyalty broadly in terms of support for the war. It was an individual's physical actions—-volunteering and providing supplies—-that defined loyalty, not one's political affiliation. "Loyal's" defense of Hatborough encapsulated how most common men and women presented the notion of loyalty during the early months of the Civil War. While a majority of the local populace defined loyalty as a unifying principle, "Loyal's" correspondence also demonstrated division amongst local residents, predominately along political lines. Hatborough was predominately a Democratic town. Furthermore, "Loyal's" letter appeared in a Democratic paper. We can see from this letter that in early in the war a surge of patriotism temporarily elevate bipartisanship to the forefront of how citizens conceptualized loyalty. However, the incident at Hatborough also revealed that such cooperation was, in fact, only temporary. ${ }^{33}$

The civilians of eastern Pennsylvania did not own a monopoly on the subject. Volunteers from eastern Pennsylvania also provided commentary on loyalty in two very specific ways. First, when men cast their enlistment in terms of loyalty, duty, or patriotic commitment to the nation, they mirrored the idea of a singular, unifying definition of loyalty that pervaded the early war years back home in Berks, Bucks, Lehigh, and Northampton counties. A second and decidedly different way that they used loyalty was in an examination of the people and places they

33 "Loyal” to Doylestown Democrat, March 4, 1862. 
encountered as they marched with their various companies and regiments. Early in the war, each of these overarching implementations of loyalty stood removed from any political discord that developed at home. However, the discussions of loyalty by eastern Pennsylvanian soldiers reinforced two important aspects that appeared from the homefront's use of loyalty. On one hand, the soldiers' conceptions of loyalty expressed the belief that early in the war they desired a nonpartisan unity, while on another hand it stressed the fact that loyalty, however broadly defined, was a way in which these men viewed the war.

When soldiers from eastern Pennsylvania enlisted in the Union Army between 1861 and 1862, they explained their rationale for taking up arms to their family and friends back home. When men such as James Peifer or John Frueauff, and a host of other men donned the Union blue early in the war, they portrayed themselves as patriotic, duty-driven, and loyal defenders of the Union. Thrice an enlistee in the Union Army, James Peifer wrote to his sister on the occasion of his first enlistment and declared that he believed "it the duty of every free and true man to defend [the flag] as long as he has the power to do it, And not allow this glorious banner to be trampled upon by these vile and vicious traitors, who are seeking to destroy this glorious liberty which we have enjoyed." Like the residents of Hatborough, or Mary Samuels and Emma Knauss, Peifer provided the American flag and the nation as a symbol to rally around, unify loyal support, and cast his enlistment as loyal. Peifer envisioned himself as an extension of the nation, someone who loyally went forth to protect the "Stars and Stripes" and the Union from destruction. $^{34}$

\footnotetext{
${ }^{34}$ James A. Peifer, Bethlehem Boy: The Civil War Letters \& Diary of James A. Peifer, Eds. Carolyn W. Able and Patricia N. McAndrew, (Bethlehem, PA: Moon Trail Books, 2007), Letter May 6, 1861 to Sister Mary. The "it" that Peifer refers to specifically relates to the American flag, so he will use the flag again as a rallying point for loyal support, which in his mind is enlisting in the Union Army. Additionally, Peifer originally promised his sister after his first three-month enlistment expired that he would not reenlist in the Union Army until he felt the country was in
} 
Peifer was certainly not alone in these sentiments as a number of other volunteers from eastern Pennsylvania also cast their enlistment as a sense of duty or a patriotic commitment to the nation. Few other volunteers explicitly used the phrase "loyal" in discussion of their enlistments, but their use of concepts such as duty and patriotism pointed towards a singular commitment to the nation. Like other residents, these volunteers articulated their loyalty in a national, apolitical vein. John Frueauff, like Peifer a native of Northampton County, defined his early desire to enlist out of a sense of duty. By fulfilling his duty to the nation, Frueauff and other soldiers asserted that they had acted loyally. They provided one of the most basic and essential actions to sustain the nation: service in the Union Army. His father disagreed, constantly challenging his son over his hasty desire to serve in the Union Army. Yet, Frueauff maintained that it was his duty to enlist and "but the logical \& natural consequence of my reasonings. ${ }^{, 35}$ His commitment to serve in the Union Army was an extension of his belief that men needed to offer themselves up for the preservation of the nation. In his "reasonings" the only true or loyal action for him to take was to enlist and support the Union war effort through physical, military service. ${ }^{36}$ Other men, such as William Reichard and Theodore Howell also cast their enlistment in terms of duty. ${ }^{37}$ Reichard from Lehigh County often referenced a desire to preserve the flag and a sense of duty to the nation as a motivation for his service. ${ }^{38}$ Howell noted in December 1862, that despite complaints at home over the costs of paying for the war that he

need of his service. Evidently, he felt the Nation's call a week later, when he enlisted again. As the war progressed and Peifer underwent a year and half long bout with health problems, he reevaluated his desire to be in the Army, became critical of the government, but continued to support the Lincoln Administration. In 1864, despite his complaints at first, Peifer reenlisted for a third time and served the duration of the war in Sherman's army as it marched to Atlanta.

${ }^{35}$ John Frederick Frueauff, Freddy's War: The Civil War Letters of John Frederick Frueauff, Edited by Daniel Gilbert, (Bethlehem, Pa: Moravian College, 2006), May 19 ${ }^{\text {th }}, 1861$ to Parents.

36 Ibid.

${ }^{37}$ William J. Reichard, The Civil War Letters of William J. Reichard, 1862-1863. In Proceedings of the Lehigh County Historical Society, Vol. 22, edited by William J. Wilcon, Esq., 136-280 (Allentown, Pa: Lehigh County Historical Society, 1958), August 22, 1862, February 11, 1863.

${ }^{38}$ Ibid., August 22, 1862, February 15, 1863. 
and his men "have done our duty cheerfully and without compulsion." 39 Enlistment was

multifaceted and complicated for the men of eastern Pennsylvania as well as for men throughout the North. Loyalty was an important way in which those men shaped part of their enlistment in a unifying, non-political message. ${ }^{40}$

Volunteers from eastern Pennsylvania also used loyalty in another way; they commented on the places and people they encountered during their service. As the men marched away from home they literally mapped loyalty, declaring some individuals or places loyal, while they found others disloyal or as they often noted "Secesh." 41 These men mapped the loyalty of both northern and southern locations, identifying places in both regions with loyal support of the nation and disloyal treason against the government. At the start of the war, on April 26, 1861 when James Peifer concluded a day of marching, he noted, "we must be satisfied here at York. We have our

\footnotetext{
${ }^{39}$ Theodore Howell, Letters, 1862-1863, Lehigh Valley Heritage Museum, Allentown, PA., December 9, 1862 to Wife. With that said, it is important to note that this point salient on the fact that men cast their enlistments in terms of loyalty, patriotism, duty, or honor, should not reference the fact that they only enlisted out of ideological beliefs as many historians adamantly believe.. Numerous historians, either in singular monographs or as parts of larger works give credence to ideological impulses for the motivation behind enlistment. The most renowned of these would be James McPherson's For Cause and Comrades, Gary Gallagher's The Union War, Chandra Manning's What This Cruel War Was Over, and Joseph Allan Frank's With Ballot and Bayonet, just to name a few. However, my research on the 153rd Pennsylvania from Northampton County while I was an undergraduate revealed that enlistment motivation for later war enlistees still held some of the rhetoric of ideological motivation, but was also motivated by the threat of the draft and socio-economic factors. The point is that enlistment motivation was complicated, not just for the destruction of slavery, the preservation of the Union, or for things like patriotism or honor. I do not suggest that these concepts did not factor into the construction of a man's rationale for enlisting, but I do believe that historians have not paid fair enough attention to the complexity of factors behind enlistment. That is however another argument for another day.

${ }^{40}$ Other soldiers, such as Stryker Wallace, Francis Stofflet, Louis Richards, and chaplain Philip Melick all also discussed duty, patriotism, or honor as motivating factors in enlistment, thereby implying a loyal commitment to the Union as a reason for their service. Philip W. Melick, Diary of Rev. Philip W. Melick, Chaplain, 153d Regiment, Pennsylvania Volunteer Infantry, 1862-63, Easton Public Library, Marx Room, November 18 and December 20, 1862; Louis Richards, Diary of the Militia Companies of 1862 and 1863, MIC 363, Historic Society of Berks County, Reading, Pennsylvania, Sept 21, 1862; Stofflet, Diary, December 12, 1862; Stryker A. Wallace, Diary of Stryker A. Wallace, Private, Co. G. 153d Pa. Vols., 1862-63, Easton Public Library, Marx Room, September 25, December 13, 1862 and June 27, 1863.

${ }^{41}$ Melick, Diary, November 18, 1862; Peifer, Bethlehem Boy, March 19, April 10, April 23, and July 27, 1862, December 10 and 26, 1863, and November 18, 1864; Richards, Diary, September 15, 1862; Wallace, Diary, December 13, 1862. 'Secesh" referenced the fact that soldiers labeled places and soldiers they encountered
} 
good water, and no pay and plenty of friends. They all go for the Union." 42 Peifer commented extensively on the loyalty of the places he visited throughout his service, citing places like Winchester and Culpepper, Virginia, along with Cincinnati, Ohio as disloyal places. Other men cited discussions with "Secesh" women and men, while volunteers like Louis Richards, noted as his unit passed through Hagerstown, Maryland that "loyal people of the place waved their handkerchiefs" at the men as they marched down one of the streets. ${ }^{43}$ Of course, the volunteers often made such assumptions after only a cursory meeting with a farmer or as they passed through a small town and their declarations of loyalty or disloyalty therefore had the potential to be inaccurate. However, the most important aspect about this mapping was not that the soldiers offered accurate assessments of the perceived loyalty of the places and people they encountered, but rather, that these soldiers processed their surroundings in terms of loyalty. The fact that men like Peifer and Richards mapped loyalty at all indicates two important and related concepts. On one hand, it indicated that the soldiers from eastern Pennsylvania mentally divided the places and people they encountered based on whether or not they adhered perceptually to a similar definition of loyalty as the soldier himself. Although these soldiers painted a particular place as loyal or disloyal, they actively used their interpretation of loyalty as a filter to understand the world around them. Like civilians, soldiers presented a singular, apolitical definition of loyalty: these individuals or places supported us as well as our vision of loyalty, while these others did not. Such an either-or paradigm however was part of the conflict that developed out of loyalty. Whoever did not condone a soldier or civilian's vision of loyalty was in fact disloyal. Through their attempts for unity, eastern Pennsylvanians established a framework that led to their division.

\footnotetext{
${ }^{42}$ Peifer, Bethlehem Boy, April 26, 1861.

${ }^{43}$ Richards, Diary of the Militia Companies, Sept 21, 1862.
} 
Just because the men and women of eastern Pennsylvania desired a united purpose did not ensure that that yearning translated into complete reality. Even early in the war men like J. J. Horn articulated a politicized, divisive version of loyalty. In his letter to the Easton Free Press in September 1861, Horn referenced a county meeting from August 19, 1861. On that evening, Democrats in Northampton County hosted their annual county meeting, drawing a large crowd of Democrats from across the county, as well as curious Republicans and soldiers returned from service in the Union Army. The crowd was so large in fact, that the meeting organizers had to move the meeting out of the county court house and onto to the nearby city-square. During the meeting, the Democrats passed resolutions that affirmed their loyalty, criticized Pennsylvania Governor Andrew Curtin for corruption, and pleaded for a peaceful resolution to the war. ${ }^{44}$ Northampton County's Congressman, Phillip Johnson then took the stage, where he criticized Republicans for starting the war to destroy slavery and defended his actions in Congress. Following his speech, when a member of the crowd was unable to ask Johnson a question, the meeting erupted into violence between the soldiers and the meeting organizers. After the meeting dispersed, a pro-Union mob marched to Johnson's house with an image of him in effigy, burnt it, and demanded a display of loyalty. Johnson professed his loyalty and stuck an American flag out one of his second story windows to placate the crowd. Appeased, but not satisfied, the mob moved on to the offices of the Argus and Sentinel, which they broke into and damaged. ${ }^{45}$

The mob's target was not incidental: the politicization of loyalty grew out of the heated rhetoric and attacks expressed by local newspaper editors. While soldiers and civilians provided a singular vision of loyalty, that of national reunification, during the early war months, their

\footnotetext{
${ }^{44}$ Easton Argus, August 29, 1861.

${ }^{45}$ Easton Free Press, August 22, 1861; Northampton County Journal, August 21, 1861; Reading Democrat and Gazette, August 24, 1861.
} 
writings contained more criticism of political opponents after the fall of 1862. Consequently, Horn's letter to the Free Press, the events of August 19, 1861, and the criticism of Hatborough's loyalty in March 1862 each serve as an appropriate transition from the early war solidarity to the more divisive use of loyalty amongst newspaper editors. There, amongst the black and white pages of newsprint, where Horn's letter and discussion of the Hatborough incident appeared, the discussion of loyalty developed very differently than amongst the personal correspondences and sentiments of the local populace.

Contrary to volunteers like James Peifer or John Frueauff and residents like Emma Knauss and "Loyal" who acted upon a national, unifying vision of loyalty, Democratic and Republican editors implemented an antagonistic version of loyalty. Much of the other literature on Civil War loyalty focused on one particular party's position on the matter, either targeting that group as disloyal or through a defense of a specific party's loyalty. My findings however demonstrate that like the citizenry of eastern Pennsylvania, members of both political parties used loyalty rhetoric as key political tools throughout the Civil War. Early in the conflict, these newspaper editors echoed the sentiments of the men and women at home, advocating unity. ${ }^{46}$ However, that sentiment barely lasted until May of 1861 . Within a few weeks of the attack on Fort Sumter, newspaper editors from eastern Pennsylvania began to criticize the loyalty of their political opponents while they affirmed their own party's commitment to the Union war effort. They abided by traditional partisan practices, which necessitated the contrast of opposites. Like civilians and soldiers, newspaper editors generated the image of the Confederacy as disloyal. They easily transferred that framework of loyalty and disloyalty onto the political stage as the war continued. As a result, eastern Pennsylvania editors demonstrated a significantly truncated

\footnotetext{
${ }^{46}$ Berks \& Schuylkill Journal, April 20, 1861; Easton Free Press, April 18, 1861; Easton Sentinel, July 24, 1862; Northampton County Journal, April 17, 1861 and July 30, 1862; Reading Gazette and Democrat, August 30, 1862.
} 
discourse of unity, one that quickly fell apart. Therefore, it was in the newspapers, once the discussion of loyalty mixed with politics by local editors that the concept of loyalty took on a divisive nature. The discussion and subsequent debate over loyalty that played out between local editors became a political tool that produced a crisis for democracy.

The traditional narrative of the Civil War presents a North unified nearly to the man in the pursuit of destroying the Confederacy after the capitulation of Fort Sumter. This common narrative ignores the political divides replete in the North, especially over the definitions of loyalty. The political divide over loyalty emerged from a conflict over how the North should go about restoring the Union. Gary Gallagher has argued persuasively that the restoration of the Union was the primary goal of the war for Northerners and that emancipation only developed as a tangential goal later in the war. ${ }^{47}$ The cry for restoration was the fundamental force that drove eastern Pennsylvanians support of the war, but Democratic and Republican editors, despite their push for unity, delineated two different working definitions of loyalty. Broadly they desired the restoration of the nation, but on a smaller level, they offered different interpretations of that reunification.

In the immediate aftermath of Fort Sumter, Democratic and Republican editors in eastern Pennsylvania debated the proper way to restore the Union. At the same time that members of both parties labored to construct their definitions of loyalty, they also attempted to reach across the prewar political divide to pull members of all political parties together behind their definition of loyalty. On the surface, local editors from both sides of the political divide crafted definitions of loyalty with a similar message. However, a careful examination reveals an early divide over the perception of loyalty. On April 20, 1861, the Reading Gazette and Democrat wrote "our

\footnotetext{
${ }^{47}$ Gary Gallagher, The Union War, (Cambridge: Harvard University Press, 2011), 3-6, 34.
} 
course is a plain one-and there is only one that a loyal citizen can take... We can know no Party but OUR COUNRTY - No duty but obedience to its laws and submission to its authority... [and that they would] support the Administration at Washington in all just and constitutional measures." ${ }^{48}$ Three days later on April 23, the Republican Bucks County Intelligencer similarly noted, "All party lines are obliterated, and all declare with a patriotic fervor unbounded, that the Union must be preserved, and its enemies routed." ${ }^{49}$ The immediate tone of both papers articulated that a key prerequisite for the support of the government during the war required the relinquishing of partisan politics and the unification of the Northern populace. These comments reinforce the conclusions of Adam I. P. Smith who noted that Americans distrusted political parties and early in the war pushed for nonpartisanship as a requirement of support for the government. $^{50}$

However, in many respects, those early articles from the Bucks County Intelligencer and Reading Gazette and Democrat offered only a shallow reflection of how their editors understood loyalty. Underneath the surface of this unifying sentiment, there were important underlying differences regarding the conceptualization of loyalty. Democrats, represented by the Reading Gazette and Democrat, stated that their commitment to the nation was contingent upon the

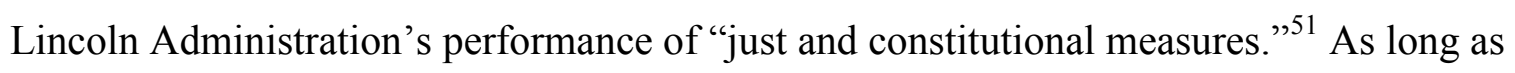
Lincoln and other Republican leaders operated within the framework of the Constitution, Democrats pledged their support to the war effort. Democrats believed that the aim of the war was for the complete and unaltered restoration of the Constitution and Union. However, if Republican leaders broke from their adherence to the Constitution, particularly in the pursuit of a

\footnotetext{
${ }^{48}$ Reading Gazette and Democrat, April 20, 1861. Emphasis in the original paper.

${ }^{49}$ Bucks County Intelligencer, April 23, 1861.

${ }^{50}$ Smith, No Party Now, 5-10, 15, 68.

${ }^{51}$ Reading Gazette and Democrat, April 20, 1861.
} 
war to destroy slavery, Democrats believed that the President of the United States as well as all public officials were "a proper subject for criticism at all times." ${ }^{, 52}$ Democratic editors throughout eastern Pennsylvania echoed the sentiment that loyalty was about the preservation of American government as it had been, perfect and unmolested. Eastern Pennsylvanian newspaper editors who supported the Democratic Party planted this theme of loyalty, one to the Constitution and Union above all other things, noting that "the Union and the Constitution, [were] more valuable than all our treasure; our civil liberties, more precious than human lives.. ${ }^{, 53}$ Therefore, while Democrats initially supported the government, they loudly reserved the right to question and criticize any action taken that they believed fell outside their vision for the war and the preservation of the Constitution. ${ }^{54}$

The belief that they could challenge any policy or action they saw unconstitutional, held by editors of the Democratic papers directly challenged the most fundamental construction of Republican loyalty. Both the Easton Free Press and Northampton County Journal published an announcement from the Union State Central Committee that defined loyalty to the nation during the war as anyone who offered "an ardent and unquestioning support to the Administrationwho sustain all measures of Congress for the maintenance of the war-making power-who see in the Southern Confederacy, and those who are in alliance with it, the enemies of Civilization and liberty." ${ }^{, 5}$ While this editorial appeared in local papers in September 1862 it reflected how Republican supporters envisioned the issue of loyalty throughout the Civil War. Republicans, as the current occupiers of the White House, viewed the Lincoln Administration and the United States government as one entity, bound inseparably together. For Republican editors at the onset

\footnotetext{
${ }^{52}$ Reading Gazette and Democrat, July 27, 1861.

${ }^{53}$ Easton Sentinel, August 29, 1861.

${ }^{54}$ Ibid., June 27, 1861.

${ }^{55}$ Easton Free Press, September 4, 1862; Northampton County Journal, September 10, 1862.
} 
of the Southern rebellion, when they physically took up arms against the Union and Constitution, there were only two options, "You must either be loyal or disloyal. You must either be a defender of your Constitution or a traitor to the Government There is and can be no middle ground. ${ }^{, 56}$ Local Democrats, on the other hand, agreed to a single party only on the grounds to defend the Constitution, but in the words of J. Lawrence Getz the editor of the Reading Gazette and Democrat, on "all other questions of public interest, there will continue to be differences of opinion. ${ }^{57}$ Getz's sentiment, shared by other Democratic editors, in turn laid the foundation for political confrontation between local Democratic and Republican editors. Democratic editors believed they had the right to question their political opponents, while Republican editors envisioned an unquestioned loyalty to the Union war effort.

From our perspective, the language of Democratic and Republican editors appears to fall nicely into categories of restoration versus reconstruction. During the war, Democrats adopted the slogan "The Union as it was, the Constitution as it is." ${ }^{, 58}$ Such a slogan is typical of a restoration line of thinking—Democrats saw the nation as perfect the way it was and believed that abolition fanaticism and Confederate recklessness brought on the war. Republicans on the other hand, who eventually came to accept the necessity of emancipation, conscription, and other centralizing measures as necessary to win the war, are traditionally regarded as reconstructionists—willing to rebuild the nation through any means possible. While these definitions are accurate in retrospect and reveal the broad contours of how the two main parties operated during the Civil War, they are less sound as a method for describing eastern Pennsylvania newspaper editors. Republican and Democratic editors throughout the war used the

\footnotetext{
${ }^{56}$ Easton Free Press, April 18, 1861. Other papers also put forward the issue of a new two party dynamic between loyalty and disloyalty_Berks and Schuylkill Journal, April 13, 1861 and Bucks County Intelligencer, April 23, 1861.

${ }^{57}$ Reading Gazette and Democrat, May 18, 1861.

${ }^{58}$ Weber, Copperheads, ix, 6, 67.
} 
language of restoration, reunification, maintenance, or preservation with less precision. It is hard and impractical to divide eastern Pennsylvanian editors along a line of reconstruction versus restoration, only because their use of language was fluid enough to obscure such characterizations. With that in mind, what we can distinguish more clearly is the ways in which editors modeled their wartime discourse off antebellum political culture, but began to transform their divisions in the context of the Civil War.

This distinction over the conceptualization of loyal support represented the first political difference that threatened the practice of democracy. Enos Prinzer, the editor of the Bucks County Intelligencer, succinctly captured this threat when he argued that anyone "who goes moping about with elongated face, anticipating bankruptcy or financial ruin to every one [as a result of the war]...is little better than an open secessionist." The sooner such complainers and naysayers were "placed under the ground", the better he felt it would be for the country. ${ }^{59}$ This was an extreme sentiment, but the underlying sentiment was shared widely. Other editors throughout eastern Pennsylvania used the language of disloyalty to attack their political opponents.

The emergence of loyalty as a politically charged element of discussion among local editors led to a distinctly different treatment of the subject in the region's newspapers, as compared to how loyalty operated in the streets. Democratic and Republican editors also cast loyalty in nationalistic terms. Members of both parties positioned loyalty in the language of defending the Union, Constitution, the flag, and the legacy of the Founding Fathers. ${ }^{60}$ The reason

\footnotetext{
${ }^{59}$ Bucks County Intelligencer, April 30, 1861.

${ }^{60}$ Editors from both parties declared that they fought the Civil War to restore the Union and the Constitution. Their use of language was remarkably similar, but the ways in which editors sought to defend the Constitution or restore the Union were rather different. Republican editors viewed the South's secession as a threat to the Constitution because it ignored the democratic process. Democratic editors disdained Southern secession, but saw the
} 
for the development of an antagonistic politics of loyalty by local editors stemmed from their divergent definitions. Democratic editors believed that they had a right to criticize the Republican administration. Therefore, when Republican leaders acted according to their values and to maintain the Union war effort, Democratic editors attacked Republicans for centralization of power, increased taxes, and the possibility of emancipation. Concerns over the emancipation of the Confederacy's slaves struck at the heart of Democratic versions of loyalty, because they believed that the Constitution explicitly protected slavery. ${ }^{61}$ There was plenty of need for concern on that account, because each Republican paper in the region eventually concluded that slavery was the cause of the country's ills. While not all Republican supporters advocated the elimination of slavery, they noted that they were willing to adopt any policy to end the rebellion. If the war destroyed slavery in the process, they did not see a problem with such a development. ${ }^{62}$ Yet, a more important point here was that as Democratic editors criticized the Republican Party, local Republican editors viewed that criticism as proof of Democratic disloyalty. They responded in kind, attacking the Democratic Party and their local editors.

The contentious discourse over loyalty and visions of the war between newspaper editors in 1861 and 1862 occurred in three ways. Regardless of their political affiliation, eastern Pennsylvania editors first attacked their local counterparts, then eventually likened the extremists of each party to Southern secessionists, and finally directly stated that their political opponents were disloyal. The ultimate goal of these actions was to convince the local electorate that their opponents were unfit to run either the local or national government to preserve the Union. These

centralization of the Federal government—increased taxes, arrests, martial law, and the infringement on slavery—as violations of the Constitution.

${ }^{61}$ Easton Sentinel, September 19, 1861, April 24, May 15, 1862; Reading Gazette and Democrat, April 27, July 7 , July 27, December 21, 1861, April 12, 19, 26, 1862.

${ }_{62}$ Bucks County Intelligencer, December 17, 1861 and June 10, 1861; Easton Free Press, April 25, July 25, November 14, December 12, 1861 April 3, and October 2, 1862; Northampton County Journal, June 4 and September 10, 1862. 
were politically designed attacks undertaken by local editors to improve their party's standing in the region. At a time when civil war literally divided the nation, the use of loyalty developed into a key element of the political discourse, with the aim to increase one party's political fortunes at the exclusion of the other. This contentious discourse started on a limited scale and expanded as the war continued.

Within eastern Pennsylvania, one of the earliest phases of the loyalty debate was when editors specifically targeted their local counterparts. In each county, the editors divided neatly against each other. ${ }^{63}$ At times the debate over loyalty came in the form of a dialogue between the editors, like when Jacob Knabb, accused the Reading Gazette and Democrat of "backsliding" in their loyalty because they discussed partisan affairs at a time when "party should be entirely lost in the sight of the party of all true patriots - that [which] supports the Union and the Constitution." 64 Getz responded that Knabb and the Journal had no right to question the loyalty of his Gazette, noting that his paper loyally served the people of Reading for twenty-one years and the Administration was "doing all it can to keep up its own party" while it cut Democrats out of political office. ${ }^{65}$ At other times, the debate was less conversational and more directed at attacking the other opposing editor. ${ }^{66}$ Their intention, regardless of political party, was to paint

\footnotetext{
${ }^{63}$ In Berks County the Berks and Schuylkill Journal spared with the Reading Gazette and Democrat, in Bucks County the Bucks County Intelligencer combated the Doylestown Democrat, in Lehigh County the Lehigh Register squared off primarily against the Allentown Democrat, and in Northampton County the Northampton County Journal (Republican) squared off predominately against the Easton Sentinel, while the Easton Free Press (Republican) mostly challenged the Easton Argus. I should note here that the Lehigh County papers were fragmentary articles that did not shed significant light on the war years. From reading local correspondences and comments in other local papers, I was able to determine the general contours of the Lehigh papers, which mirror the ones in Berks, Bucks, and Northampton Counties.

${ }^{64}$ Berks and Schuylkill Journal, May 25, 1861.

${ }^{65}$ Reading Gazette and Democrat, May 25, 1861.

${ }^{66}$ Some instances of Republicans attacking local Democratic presses occurred: Berks and Schuylkill Journal, May 25, 1861 August 2, 1862; Bucks County Intelligencer, June 3, 1861, June 3, 24, September 23, 1862; Easton Free Press, April 25, May 2, July 11, August 15, 1861, February 2, March 6, August 14, 1862; Northampton County Journal, May 15, 1861 August 21, 1861.
} 
their opposition as partisan, focusing on their own political interests, thereby positioning them as disloyal. Yet at the same time these editors made the accusations of disloyalty, they also limited those claims to select individuals. The rational for such limitations was that editors still professed a desire for nonpartisan unity. In order to attract individuals to a nonpartisan interpretation of their version of loyalty, editors wanted to target specific individuals, question their loyalty, and attract larger segments of the other party to their side.

Yet as the war continued, Republican and Democratic editors expanded their focus beyond their individual counterparts and began to criticize broader segments of the political opposition as disloyal. The first step in this direction was to target the extremists from the opposing party and liken them to secessionists. Democrats targeted abolitionists and Republicans who sought to destroy slavery, while Republican editors focused on any Democrats that advocated for peace at any price or questioned the Lincoln administration. ${ }^{67}$ In either case, members of both parties conflated specific segments of the opposing political party with the rebelling states. Similar to J. J. Horn's letter at the start of this paper, where he noted that he would place Northampton County in league with secessionist counties in Virginia if local residents elected a Democrat to office, newspaper editors drew direct comparisons between their opponents and the largest agreed upon disloyal element on the continent: the Confederacy. Often, editors declared that the Union needed to stomp out "traitors North and South."68 The implication of comparing Republicans or Democrats to the seceded states was intended to illicit a

\footnotetext{
Some instances of Democratic editors attacking local Republican presses occurred: Easton Argus, May 23, 1861; Easton Sentinel, April 25, May 2, 30, 1861; Doylestown Democrat, February 4, 11, March 11, 1862; Reading Gazette and Democrat, July 6, 1861, April 26, July 19, 1862.

${ }^{67}$ Berks \& Schuylkill Journal, August 2, 1862; Bucks County Intelligencer, June 10, 1862; Easton Argus, June 5, August 18, October 30, 1862; Easton Free Press, May 23, 1861 and August 4, 1862; Easton Sentinel, February 27, May 15, August 21, 1862; Northampton County Journal, September 11, October 23, 1862; Reading Gazette and Democrat, February 1, June 14, August 9, 1862.

${ }^{68}$ Northampton County Journal, September 14, 1862.
} 
common object that Northerners could agree on as disloyal. At the start of the war, eastern Pennsylvanians used events like War Meetings along with a useable past to construct an image of the North as loyal and the Confederacy as disloyal. Editors likened extremists of their opposition to the rebels because it directly conjured images of traitors and disloyal Americans already established by the desire for a unified, apolitical war effort at the start of the conflict.

In time, eastern Pennsylvanian editors eventually targeted all their political enemies as disloyal. As the war progressed and as members of each party infringed further upon the other's definitions of loyalty, whether it was discussion of slavery or criticism of the Lincoln Administration, Democratic and Republican editors characterized their opponents as disloyal. Local editors conflated the opposition with secessionists and declared that their political opponents were disloyal. By the summer of 1862, the limited criticisms of loyalty used by local editors at the start of the war gave way to larger and more specified attacks against the other party. This form of discourse over loyalty, as well as the attacks on local editors and the conflation of political party with secessionism represented a drastically different vision of loyalty than amongst the local citizens at their war meetings, flag presentations, or reflections on enlistment. The difference was that local editors wanted that definition to benefit their party at the exclusion of their political opponents. ${ }^{69}$

In addition to the direct attacks over loyalty, we can see the attempts to ostracize political opponents and create a single, politicized version of loyalty through the language Democratic and Republican editors used in their papers. Editors used the language of loyalty in two specific ways throughout eastern Pennsylvanian newspapers. The first was the use of derogatory

\footnotetext{
${ }^{69}$ Berks and Schuylkill Journal, July 5, 12, September 27, 1862; Bucks County Intelligencer, June 3, 1862; Easton Free Press, April 24, June 8, July 17, 1862; Easton Sentinel, June 5, August 14, 1862; Northampton County Journal, August 23, 27, October 15, 1862; Reading Gazette and Democrat, June 14, 1862.
} 
nicknames for their partisan opponents. Editors used these nicknames throughout the war to engender feelings of distrust and disloyalty about their opponents. Democratic editors relied on names that corresponded to the issue of race and emancipation. As a result, they often substituted the term "Abolitionists" or "Black-Republicans" for their Republican counterparts. ${ }^{70}$ Comparatively, Republican editors focused on terms that discredited the legitimacy of the Democratic Party, using nicknames such as "Breckinridge Democrats" to address their rivals. ${ }^{71}$ "Breckinridge Democrats" referred specifically to John Breckinridge, former candidate for the Presidency in 1860 and eventual general in the Confederate Army. The intention here was to use Breckinridge's defection to the Confederacy, his literal betrayal of the nation, to infer that Democrats were also disloyal traitors. Each example strove to use a single word to position political opponents as disloyal entities. A second way that editors' language created a politicized loyalty was their casual references that only a single definition of loyalty existed. Both Democratic and Republican used phrases such as "all loyal citizens", "loyal people", and "true Union men" throughout their publications. ${ }^{72}$ While simplistic, the use of such phrases suggested that only one type of loyalty existed throughout the North. Editors implied that their version of loyalty, their views on the war, and only those people who adhered to those principles were loyal. These two specific uses of language and loyalty point to the fact that newspapers, directly through their debate over the meaning of loyalty and indirectly through their use of language, attempted to influence the residents of eastern Pennsylvania into supporting their version of loyalty.

\footnotetext{
${ }^{70}$ Easton Sentinel, May 23, June 27, December 12, 1861, April 17, July 10, August 21, 1862; Reading Gazette and Democrat, February 1, April 19, 26, June 14, August 9, 1862.

${ }^{71}$ Berks and Schuylkill Journal, August 2, 1862; Bucks County Intelligencer, July 23, 1861, June 10, 1862; Easton Free Press, October 2, 1862; Northampton County Journal, October 23, 30, 1861, June 4, July 16, August 27, 1862. ${ }^{72}$ Berks and Schuylkill Journal, September 28, 1861; Bucks County Intelligencer, July 2, 1861 and September 30, 1862; Easton Sentinel, June 27, 1861; Northampton County Journal, October 23, 1861; Reading Gazette and Democrat, May 25, 1861 and July 26, 1862.
} 
As these examples illustrate, partisan newspaper editors articulated a drastically different vision of loyalty than that of the local residents. Newspaper editors and the papers they published influenced the discourse over loyalty in two specific ways. First, editors served as the mouthpieces for both the Republican and Democratic parties in Berks, Bucks, Lehigh, and Northampton counties. Editors presented the ideas of their party, through their own personal correspondences, but also through the publication of resolutions passed at county, state, or political meetings as well as through the publication and commentary on political speeches. Editors did not necessarily generate political policy, although in Northampton County, the local residents elected the Sentinel's editor Daniel H. Neiman to the state legislature for the 1862 term. ${ }^{73}$ Yet, largely, eastern Pennsylvania editors did not so much shape policy as they disseminated their political opinions to the local populace. Second, by relaying the ideas of their own political party, newspaper editors implied that their version of loyalty was correct while competing definitions were not. As a result, newspaper editors were one of the primary means through which eastern Pennsylvanians learned about the war and how political partisans understood the conflict.

Another way to consider the importance of loyalty as a means of political discourse is to understand when eastern Pennsylvania newspaper editors used the term loyalty. Throughout the entirety of the Civil War, the discussion of loyalty in local papers developed a clear pattern. In particular, the months that surrounded elections, typically July until October or November of any year, witnessed multiple and extensive discussions of loyalty in each paper. However, immediately following the conclusion of any election and the announcement of the election's results, commentary about loyalty dropped off considerably. Newspaper editors provided little

\footnotetext{
${ }^{73}$ Easton Sentinel, November 14, 1861.
} 
discussion of loyalty, either defending their own party's loyalty or attacking that of their opponents, between mid-November and February of the following year. ${ }^{74}$ Around the late winter and early spring the arguments picked up again slowly in time for local elections and gained intensity as the calendar pressed closer to the summer. The Bucks County Intelligencer accurately displayed the connection of loyalty to campaign seasons in 1862 when it ran a masthead on the first page that read "For the Union and the War-No Compromise or Sympathy with Traitors" between July and October of that year. ${ }^{75}$ The fact that local editors, such as Enos Pinzer, J. Lawrence Getz, and William Hutter printed discussions of loyalty around the times of elections ties the concept of loyalty firmly to the political discourse of the war years. Therefore, local editors not only used loyalty as a political tool to attack their opponents and discredit them, but they also presented those attacks around a rigid schedule that conformed to the political campaign season. $^{76}$

As newspaper editors expanded their attacks against one another and the opposing party through the language of loyalty, they established the foundation for a crisis of the democratic process. These accusations of disloyalty that positioned one party's interpretation of loyalty as correct were political maneuvers undertaken by eastern Pennsylvania newspaper editors.

Republican or Democratic editors positioned their party as the only loyal party, the only true "Union" party in eastern Pennsylvania and the North writ large. As editors increasingly relied on loyalty as their language of political critique, they came to see political adversaries as threat to

\footnotetext{
${ }^{74}$ In this instance, I stretched beyond 1861 and 1862 because the cycle of how newspaper editors discussed loyalty throughout the war was an important indicator of the concept's politicized nature. In each year from 1861 through 1865 , the appearance of loyalty ebbed and flowed with the timing of political elections.

${ }^{75}$ Bucks County Intelligencer, July 9, 1862 until October 7, 1862. In 1863 and 1864, the Intelligencer provided other taglines that ran through the election cycle. In 1863 their masthead read "No Sympathy to Traitors and Copperheads" and in 1864 "For the Prohibition of Slavery by a Constitutional Amendment."

${ }^{76}$ This statement should not indicate that all discussion of loyalty ceased after mid-November and returned in February of the next year. Rather, the point more precisely is that during the war the appearance of loyalty ebbed and flowed with the contours of political campaign seasons.
} 
the nation. Eastern Pennsylvanians began to reshape their political discourse, from a two-party system that permitted disagreement - in some instances needed that disagreement for parties to legitimize themselves against their opponents - to a rhetorical system that associated disagreement with disloyalty. This hostility added to a period of contentious American political discourse that began before the Civil War. In the 1850s, average Americans and political partisans increasingly displayed a derisive form of political debate. Scholarship from the past several decades indicate that such discourse was not limited to one part of the nation. Within American cities between 1850 and 1865, Mary Ryan demonstrated that physical violence and confrontation came to dominate the democratic process as the public transitioned from ethnic divisions to racial and political divisions and as individuals strove to establish their place in the political process. ${ }^{77}$ Elizabeth Varon likewise demonstrated that the rhetoric of disunion exacerbated divisions between the antebellum North and South as well as the fact that accusations of disunion continued well into the war years. ${ }^{78}$ Eastern Pennsylvanians demonstrated both change and continuity from antebellum political culture. They maintained a two-party system, where political opponents needed to legitimize their party in competition with a less worthy by still legitimate opponent. They called on notions of antipartisanship and connections to the Revolution, Constitution, and Founding Fathers to demonstrate their party's loyalty. However, the context of the Civil War was different. While antebellum partisans disliked their opponents and criticized the harm they could do to the nation, the Civil War provided a moment where the sentiments of the opposition were no longer just harmful to the nation they

\footnotetext{
${ }^{77}$ Mary Ryan, Civic Wars: Democracy and Public Life in the American City During the Nineteenth Century, (Berkley: University of California Press, 1997), 129, 131, 136, 140-2, 170-3.

${ }^{78}$ Varon, Disunion. We can also see a crisis over democracy in the South, particularly from Stephanie McCurry's Confederate Reckoning. Although an entirely different region from eastern Pennsylvania, McCurry looked at the experience of the Confederacy and her examination of secession illustrated that in various parts of the region, such as Georgia, duplicity influenced secession, ignoring the democratic results of secession conventions.
} 
could be downright destructive. Newspaper editors drove most of the early conflicts over loyalty in eastern Pennsylvania, but that was only a precursor of what was to come.

After the fall of 1862 the rhetoric of politically minded, divisive loyalty began to appear more frequently in the correspondences of ordinary individuals, soldier or civilian. Changes in military policy undertaken by the Lincoln administration sustained this transformation. While Lincoln and his generals transitioned the Union Army from a policy of a quick, short war, to a "hard" conflict intent on dismantling the South's ability to make war predominately through the destruction of slavery as well as the curtailment of civil liberties played a major part in the reconceptualization of loyalty. Democrats responded harshly to the Emancipation Proclamation and curtailed freedoms, because in their eyes those actions violated the Constitution. As a result, Democratic editors lambasted Lincoln, his administration, and Republicans on a far wider scale. They likened Lincoln to John Adams, who they saw as a tyrant with an administration that had "usurpation and corruption, official oppression, war against freedom of speech and of the press, burdensome taxes, stamp and gag laws, imprisonment for opinions sake, armies of tax collectors, abuse of power, and outrageous persecution of all democrats." ${ }^{, 79}$ Republicans and their local editors in turn saw such criticism as proof of Democratic disloyalty and treason. They responded in kind, further comparing Democrats in eastern Pennsylvania to the traitorous Confederacy. After the1862 elections in Berks County, Jacob Knabb noted that while loyal men went off to fight and put "down this infamous Rebellion of the Breckinridge party against the Government, the Breckinridge party in the North, have staid at home to aid their brethren by a cowardly and bloodless fight at the ballot box." ${ }^{80}$ Knabb's point was that Republicans had enlisted in the Union Army in order to preserve the Union, while Democrats remained at home, unwilling to sustain

\footnotetext{
${ }^{79}$ Easton Argus, October 16, 1862.

${ }^{80}$ Berks and Schuylkill Journal, October 18, 1862.
} 
the nation. Instead, he implied, Democrats stayed home in order to aid the Confederacy by undermining the Union during elections. For Knabb, Democrats as a whole actively worked to sabotage the war effort by not enlisting and voting for candidates sympathetic to the Confederate cause. After the announcement of the Emancipation Proclamation in September 1862, visions of loyalty began to change and any restraint held by local editors containing the loyalty debate dissipated.

While political discussions increased in their ferocity around the same time of the Emancipation Proclamation, the debate over loyalty began back in May 1861 for newspaper editors. The discussion about loyalty between newspaper editors helped shift the attitudes of local men and women from a unified vision of loyalty to one that was more contentious and divisive. The actions of the Union mob on August 19, 1861 in Easton, Pennsylvania targeted the offices of both the Argus and Sentinel. The motivation behind the attacks was the perception amongst the mob that both papers and their editors were disloyal to the Union war effort. ${ }^{81}$ Newspapers, in that sense, motivated the crowd to attack what they deemed as disloyal presses. Two more examples, from later in the war, highlight the importance placed on newspapers for the transmission of sentiments about loyalty. In May of 1863, G. W. Kramer from Lehigh County wrote to his friend Henry Hornbeck with the Union Army in Florida at the time. Kramer inquired if Hornbeck wanted a newspaper sent to him and if so what kind. If, in Kramer's eyes, Hornbeck wanted a Democratic paper, then he wanted the "Constitution As it is, and the Union as it was." However, if Hornbeck desired an "Abolition Paper" he therefore desired the "Contrary, the Union dissolved, and the "Nigger's" emancipated." ${ }^{82}$ Kramer clearly positioned

\footnotetext{
${ }^{81}$ Easton Free Press, August 22, 1861; Northampton County Journal, August 21, 1861.

${ }^{82}$ Henry Jacob Hornbeck, Diary of Civil War Service by Henry Jacob Hornbeck September 1862-June 1864, (Lehigh Valley Heritage Museum, Allentown, PA), GW Kramer to Henry Hornbeck, May 7, 1863.
} 
Hornbeck's choice as a political one. Another example, also from Lehigh County, came from William Reichard, when he noted in the winter of 1863 that several soldiers in his company received Democratic papers from home. Reichard expressed his displeasure, as well as the displeasure of his unit, to his family at home for the insults and slanders of the Democratic press from Lehigh County. The unit's resentment was so strong that they passed resolutions that spring which condemned the traitorous language of the local Democratic presses ${ }^{83}$ Each of these examples highlighted the fact that newspapers served as a viable vehicle for the transition of the debates over loyalty and provoked strong reactions from residents and volunteers from the region. Eastern Pennsylvania newspapers and their editors played an important role in transforming the debate over loyalty from an apolitical loyalty based on participation to a partisan definition that equated partisanship with loyalty or disloyalty. That transition laid the foundation for a democratic crisis because eastern Pennsylvanians came to see their political opponents as a threat to the nation.

The use of loyalty amongst eastern Pennsylvanians began as an expression of unity and nonpartisanship (hallmarks of antebellum antiparty feeling). Soldiers, civilians, and even for a fleeting moment editors, positioned the Civil War as a contest between a loyal North against traitorous Confederacy that sought to destroy the nation. However, this framework allowed individuals to introduce the concept of loyalty and disloyalty into the narrative of the war. The definitions of loyalty produced by newspaper editors, while they preached the disregard of partisanship, provided a conception of loyalty that challenged their opponent's definition. What transpired was cyclical. As the war continued, growing more perilous with each passing day,

\footnotetext{
${ }^{83}$ Reichard, Letters, January 31, March 29, April 19, and April 21,1863. Reichard also provided commentary about the Republikaner on February 15 and 16, 1863 in letters to his brother and brother-in-law respectively. Both letters further painted a negative picture of the influence and treasonable actions of the Democratic Republikaner.
} 
Lincoln took steps he deemed would ensure the Union's victory—the emancipation of Southern slaves, the curtailment of certain liberties, and conscription. Democratic editors in eastern Pennsylvania viewed these actions as disloyal because in their opinion such actions stepped outside the boundaries of the Constitution. As they began to criticize Republicans for their conduct of the war, local Republican editors saw such attacks as proof of Democratic disloyalty, violating their principles of unquestioning support for the administration in power. As the rhetoric of loyalty returned to traditional forms of the two-party system, it slowly influenced the local citizenry and set the stage for a crisis, where partisan affiliation would come to represent either a threat or a boon to the Union war effort. 


\section{Chapter Two}

\section{Dangerous Divisions: Loyalty and the Crisis of Democracy, 1863-1864}

"Have the days of the Spanish Inquisition returned?" Captain Joseph A. Frey of the 153rd Pennsylvania Volunteer Infantry Regiment asked the three-man committee of "The Society of Home Friends of the Bethlehem Volunteers" on January 15, 1863. Previously, the "Friends" wrote a letter to Frey that questioned his politics and loyalty to the nation as the Civil War passed into its third year. The letter angered Frey, prompting a response that he penned to Edward Doster, John Lerch, and David H. Taylor, the three Bethlehem-ites who composed the committee. He also sent a copy of his letter to Daniel Neiman so that his reply would reach a larger audience through the pages of the Easton Sentinel. As a "free white citizen of the U. States," Frey believed that he deserved recognition of certain privileges, one of those being the freedom of speech allowing him to express his politics and sentiments about the war effort. Insulted "by a set of MEN, mark the words, not gentlemen" who remained at home, replete in courage or patriotism so much so that they failed to enlist in the Union Army, Frey proposed an alteration to the title for The Society of Home Friends of the Bethlehem Volunteers. In place of the word "Friend," he urged the organization to substitute the term "Enemies" in order to produce a more accurate picture of their relationship to local soldiers, the Union, and the war effort. ${ }^{84}$

Frey's letter serves as a counterweight to the extract published in the Easton Free Press on September 19, 1861 from J.J. Horn that criticized "Northern Sympathizers," the Democrats he found lacking in loyalty throughout Northampton County prior to the local election in $1861{ }^{85}$

\footnotetext{
${ }^{84}$ Easton Sentinel, January 1, 1863.

${ }^{85}$ Easton Free Press, September 19, 1861.
} 
Frey's criticism of the "Friends" targeted the Republican (or Unionist) populace of Bethlehem. ${ }^{86}$ Aside from the role reversal that found supporters of the Republican Party under criticism from a Union soldier, the exchange between Frey and the "Friends" more aptly demonstrated how extensively the use of loyalty changed after the fall of 1862. Between April 1861 and the fall of 1862, individuals like Horn, who criticized the loyalty of political opponents, were uncommon outside the columns of regional newspapers. Unlike the newspaper editors, average men and women from Berks, Bucks, Lehigh, and Northampton counties, strove for a singular, unifying definition of loyalty and national allegiance. However, as the war continued, changes in Republican policies - the suspension of habeas corpus, the introduction of conscription, increased taxation, and the announcement of emancipation as a war measure-changed the nature of the loyalty debate. These actions specifically violated Democrats' interpretation of the Constitution, representing a fearful and disloyal centralization of power. Republicans believed these measures represented sound policies to defeat the Confederacy. After the fall of 1862 and the announcement of the Emancipation Proclamation, ordinary individuals reformed their views on loyalty. Influenced by the derisive discussion of political loyalty from newspaper editors, soldiers and civilians altered their vision of loyalty to cast their political opponents not only as disloyal, but also as a threat to the survival of the nation.

In a broad sense, this transformation appeared to rekindle an old pattern, because eastern Pennsylvanians in the latter part of the war adopted something similar to the traditional antebellum political discourse, which positioned political opponents as threats to the American

\footnotetext{
${ }^{86}$ During the war, eastern Pennsylvanians, like many Northern Republicans transitioned into the Union Party. Adam I. P. Smith's No Party Now acknowledged this transition as an asset for Unionists, because they could claim antipartisanship, blaming Democrats for being adherents to party principals during the Civil War. While this is true of eastern Pennsylvanians, I refer to them throughout as Republicans, because during the war their definition of loyalty remained unchanged. While their official name may have changed, their stance on loyalty remained the same, hence my decision to maintain the dichotomy of Republicans and Democrats reflects the consistency of their interpretation of loyalty.
} 
nation. Yet, this transition amongst local men and women created the central focus of the crisis of democracy that developed in later 1862 and carried throughout the war. Context is key, because despite the similarities, there was a distinctly different tone present in the political discourse after the fall of 1862 . That difference the rhetoric of loyalty used by Republicans and Democrats in eastern Pennsylvanian pushed the each side to view their opponents in nearly apocalyptic terms, because the war provided the opportunity for political adversaries to legitimately subvert the nation. Frey's exchange with the Bethlehem "Friends" is indicative of the changes experienced by the local population in 1863 and 1864 . His intense resentment, aimed at Republicans back home in Bethlehem became the norm for soldiers and civilians. ${ }^{87}$ This second chapter will highlight how the use of loyalty went from a unifying agent among local residents of eastern Pennsylvania to a divisive concept. Soldiers and civilians demonstrated the most dramatic divergence from their discussions of loyalty expressed earlier in the war. On the other hand, while soldiers and civilians evidenced a substantial change in their use of loyalty, local newspaper editors maintained a steady course. They continued to paint their political rivals as dangerous enemies to the Union's ability to restore the nation. More important than the change or continuity express by soldiers, civilians, and editors is the events surrounding the war's latter years in eastern Pennsylvania. Two key political elections, the Pennsylvania Gubernatorial Election of 1863 that pitted Republican incumbent Andrew Curtin against Pennsylvania Supreme Court Judge George Woodward and the national Presidential Election of 1864 between Lincoln and General George McClellan, dominated the political agendas of both parties. These two elections, with the increased discontent among the local populace and

\footnotetext{
${ }^{87}$ John Frueauff, another captain in the 153rd Pennsylvania, noted in a letter to his family that he found the exchange "ridiculous." Both sides, he argued were at fault, the committee of "Friends" for failing to level specific charges and Frey for his "blackguard answer." Though Frueauff also added that Frey's "loyalty is very certainly not in my opinion unquestionable." Frueauff, Freddy's War, Frueauff to Parents, January 25, 1863.
} 
continued debate over loyalty by newspaper editors produced a crisis in American democracy, because they were major elections during the war. Context was important. In 1861 and 1862 the residents of eastern Pennsylvania established foundations for such a crisis when they positioned the Confederacy as disloyal and cast their experience in terms of loyalty. In the process, they inadvertently created a crisis for democracy, because each side presented elections as enabling either the saving grace or the portent of destruction for the nation. Because, as the war progressed, the increasingly politicized use of loyalty conjoined political affiliation and loyalty for ordinary men and women throughout eastern Pennsylvania. During these elections, ordinary citizens and newspaper editors positioned their political opponents as a threat to the Union, while their party represented the only possible means to save the country. The result was that the democratic process itself ironically became both the path to salvation for the Union as well as the means of its destruction. While the general contours of this crisis reflect an intensification of antebellum political discourse, the utterly different context of a real civil war made this rhetoric much more dangerous. America's Civil War presented a tangible experience where the accusations of disloyalty and the associated destructive possibilities of an opponent's election had a legitimate possibility of irreparably destroying the nation, thereby increasing the hostility between political partisans in eastern Pennsylvania.

Both Democrats and Republicans wanted to restore the fragmented nation, but they had different visions on how to accomplish that restoration. Too often, the Republican criticism that Democrats opposed the reunification of the nation becomes the traditional narrative. For example, Jennifer Weber argues that the Copperheads represented a concerted, effective political movement that seriously threatened the Union's war machine. ${ }^{88}$ Implicitly though, such an

\footnotetext{
${ }^{88}$ Weber, Copperheads, 10-2, 25-6.
} 
interpretation takes the stance that Copperheads were disloyal. Yet in eastern Pennsylvania, both parties advocated for a successful conclusion to the war, reuniting the country. Democrats and Republicans both lauded Union military triumphs and bemoaned their reverses. Political discord did hinder the war effort, but it took both parties to generate that disagreement and division. Mark Neely has noted that the two-party system "was not $a$ vehicle for communication," but rather "Each party and its noisy newspapers constituted vehicles of communication with very different messages for the northern people." ${ }^{89}$ Eastern Pennsylvanians from either side of the political divide constantly discussed their vision of loyalty as the only sure way to win the war. Members of both parties wanted the same thing — the Union restored — but they had different views on how the North should reach that goal. The use of loyalty throughout 1863 and 1864 should further demonstrate the need to use loyalty as an organic construct that members of both parties used to attack their opponents, as well as an element through which ordinary men and women understood the Civil War.

In the wake of emancipation, the first place to turn in order to understand the extent to which the loyalty debate transformed after the fall of 1862 is to examine the soldiers and citizens of eastern Pennsylvania. Around the autumn of 1862 and Lincoln's announcement of the Emancipation Proclamation the use of loyalty amongst the ordinary men and women in eastern Pennsylvania began to change drastically. In the field, soldiers still used loyalty to justify their enlistment, although this dropped off noticeably later in the war. Those volunteers continued to reinforce their patriotic, duty-driven, loyal commitment to the nation, while they also remained cognizant of the perceived loyalty of the people and places they encountered. ${ }^{90}$ Similarly,

\footnotetext{
${ }^{89}$ Neely, The Union Divided, 186.

${ }^{90}$ Frueauff, Freddy's War, December 10, 1862; Hornbeck, Diary, January 29, 1863 and June 2, 1863; John Peter Kern Kohler, Civil War Record of Dr. John Peter Kern Kohler of Egypt, Lehigh County, PA., November 9, 1862. A
} 
ordinary residents at home maintained at least a superficial desire for unified loyalty. ${ }^{91}$ However, collectively, soldiers and civilians began to implement a discourse that used loyalty as a politically oriented, divisive concept. We can see this development in two specific ways. The first is the insertion of direct, specific attacks levied at political opponents coupled with accusations of disloyalty that clearly ushered in new and specific uses of loyalty. A second approach is through the language implemented by the residents of eastern Pennsylvania. Much like the newspaper editors interjected nicknames and specific phrases to imply loyalty or disloyalty earlier in the war, eastern Pennsylvanians adopted similar language around September 1862, which pointed to this increasingly antagonistic use of loyalty.

For most, but by no means all, of the volunteers from eastern Pennsylvania, the Democratic Party became the target of the soldiers' criticisms and accusations of disloyalty. Their criticisms against Democrats took on a variety of shapes and forms. Many of the soldiers believed that Democrats, or as they frequently termed them, Copperheads or Northern Secessionists, were in the words of William Reichard "Traitors at home." In a discussion with his brother-in-law, he argued they "were worse than the rebels, for the latter do their things openly, but the former are so base and deluded that they would (as you write) destroy the Government rather than see the Republican party in power." ${ }^{92}$ Reichard specifically charged Democrats with disloyalty. In Reichard's mind, Democrats posed a threat because if they were not in power they would seek to destroy the government. Other soldiers echoed Reichard's point,

920 K, Lehigh Valley Heritage Museum, Allentown, Pennsylvnaia; Samuel D. Lehr, Letter to Sir July 16, 1863, $176^{\text {th }}$ Regiment, PA Vols, MSS PF 502 LEHR Lehigh Valley Heritage Museum, Allentown, Pennsylvania; Reichard, Letters, February 11, 1863; Peifer, Bethlehem Boy, November 7, 8, 13, 17, December 10, and 26, 1863 and November 19, 1864; Stofflet, Diary, December 13, 1862 and February 5, 1863.

${ }^{91} \mathrm{We}$ can see this impetus around events like the invasion of Pennsylvania in 1863 culminating at Gettysburg and war meetings held towards the end of the war that presented a unified front. Bucks County Intelligencer, September 22, 1863; Easton Argus, July 2, 1863, July 21, 1864; Doylestown Democrat, September 15, 1863; Northampton County Journal, July 1, 1863, December 9, 1863; Easton Sentinel, July 2, 1863.

${ }_{92}$ Reichard, Letter to Brother in Law, February 16, 1863. 
noting that they distrusted and feared "Copperheads" because they were a disloyal threat to the Union war effort. ${ }^{93}$ The fact that local volunteers viewed Northern Democrats as a shadowy, disloyal force that sabotaged the Union war effort signified the transformation of loyalty. Such comparisons reflect Richard Hofstadter's description of a "paranoid style" in American politics. Hofstader argued that Americans from the eighteenth century to the present used hyperbole to present political opponents or specific groups (Hofstadter's article cites Masons and Catholics as two examples) as a conspiring threat against the nation. ${ }^{94}$ Soldiers reverted to this style of discourse, but what sets their comments apart from traditional paranoid style is the fact that the Civil War itself presented a potential disaster for the nation. As such, this discourse demonstrated three things about the discussion of loyalty later in the war. First, that volunteers expanded their vision of loyalty to include the people and politics back home. Disloyalty was no longer just a concept that they encountered on the march, but something they could find at home. Their new discussions of loyalty drew family, friends, and their local community into the conversation. ${ }^{95}$ Second, their new use of loyalty demonstrated that the politicization of loyalty had expanded beyond the newspapers into the conversations of the volunteers. Much like the periodical publications, soldiers began to conflate partisan affiliation and loyalty with greater frequency.

Third, the discussions about loyalty put forward by local volunteers were far from solitary pursuits. Reichard's February $16^{\text {th }}$ commentary went to his brother-in-law, but throughout his service Reichard also engaged in a series of correspondences with his father,

\footnotetext{
${ }^{93}$ Jonathan Clayton, to Friend Tip, October 20, 1864, Hibbs Family Collection, Bucks County Historical Society, Doylestown, Pennsylvania; Frueauff, Freddy's War, February 7 and 12, March 19, 28, April 12, and May 16, 163; Peifer, Bethlehem Boy, January 13, August 24 and 29, November 7, 1864; Reichard, Letters, January 31, February 15, 16, March 9, 19, 28, and 29, 1863.

${ }^{94}$ Richard Hofstadter, “The Paranoid Style of Politics," Harpers Magazine, (November 1964), 77-86.

${ }^{95} \mathrm{We}$ can see this in the ways in which soldiers discussed loyalty. Early in the war they focused on their own motivations or reflectively on the people and places they encountered. During late 1862 and throughout both 1863 and 1864, soldiers engaged their families more directly about the broader concept of loyalty as well as the loyalty of their home communities.
} 
sisters, and brothers about loyalty. At one point, he wrote to his sister Sallie "you ask why traitors at home are allowed to print and spout treason; we have often spoken of it ourselves, and come to the conclusion that the government is [much] too lenient in its treatment of Copperheads." 96 This conversation between brother and sister reveals a great deal about the new contours of loyalty. On one hand, Reichard noted, "we have often spoken of it ourselves," referring to the men in his regiment. Soldiers in camp, around their fires, and among their friends discussed the concept of loyalty. Likewise, Reichard revealed that soldiers also communicated with loved ones back home about loyalty. He was not alone. John Frueauff wrote his parents about Frey's correspondence with "The Society of Home Friends of the Bethlehem Volunteers" calling the whole affair "ridiculous" for both sides. He believed that the Society should have made more specific charges rather than blanket accusations, but stated that Frey mishandled the situation. Furthermore Frey's "loyalty is very certainly not in my opinion unquestionable."97 Like Reichard, Frueauff revealed intra-family discussions of loyalty. He further revealed that soldiers categorized the loyalty of the men they served with in the Union Army. Other volunteers, such as Philip Melick and James Peifer also noted that political debates raged through their units in 1863 and $1864 .{ }^{98}$ Peifer (who also wrote to his sister) noted that the war developed into a conflict that could "only have two parties, Union or dis-Union, and the great rebellion can only be crushed then; when have put down the traitors we have at home, which are worse than the southern." 999 Peifer echoed the language of early war Republican editors by adopting a politically divisive approach to loyalty.

\footnotetext{
96 Reichard, Letter to Sister Sallie, March 29, 1863.

${ }^{97}$ Frueauff, January 25, 1863.

${ }_{98}$ Melick, Diary, June 11, 1863; Peifer, Bethlehem Boy, September 26, 1864.

${ }^{99}$ Peifer, Bethlehem Boy, October 13, 1862.
} 
Other volunteers, such as Henry Hornbeck and Beates Swift, both Democrats, also incorporated politics and loyalty into their criticisms of the war. In his diary, Hornbeck noted that Republicans practiced "Political Knavery.” In June 1863, they replaced the Quarter Master of his regiment with a man "from behind a Counter in a New York Store," sent to the regiment by "those in power, to relieve an excellent volunteer officer. thus are affairs managed at present, good Men thrown overboard and Politicians substituted.” The result prompted Hornbeck to wonder about the Union's ability to subdue the Confederate Rebellion "when such glaring evils are daily taking place, and of date, More frequent than ever." ${ }^{100}$ Hornbeck criticized Republicans for their "misrule and mismanagement" as they guided the nation through the war and questioned their ability to restore the nation. ${ }^{101}$ Hornbeck's message was twofold. He believed that Republican actions had base political motivations and he believed that Republicans in power acted solely to benefit their party functionaries. As a result, Republicans acted disloyally, placing party performance over the restoration of the nation.

Comparatively, Swift, a lawyer by training, began the war as a devout Republican who enlisted in the Union Army on August 8,1862, but shortly thereafter had a change of political heart. ${ }^{102}$ His enlistment came in time for him to march with the 129th Pennsylvania to the Battle of Antietam. After seeing the carnage near Sharpsburg, Maryland, Swift fell ill, entered a Union military hospital, and by December 1862, four months after he patriotically enlisted, he was home and in the process of being discharged from the Army. ${ }^{103}$ During those four months, he

\footnotetext{
${ }^{100}$ Hornbeck, Diary, June 13, 1863.

${ }^{101}$ Ibid., July 16, 1863.

${ }^{102}$ Beates R. Swift, The 1863 Diary of Beates R. Swift: A Year in the Life of an Easton Youth During the Civil War, Ed. Ned D. Heindel, (Easton, Pennsylvania: Northampton County Historical and Genealogical Society, 2004), 8. Heindel's transcription of Swift's diary, while illuminating of Swift's experiences and political transformation, is a frustrating read. Heindel evidently read Swift's diary, but wrote a narrative of his experiences, only occasionally citing (aside from several pages at the end of the text) very little of what Swift said directly.

${ }^{103}$ Swift, 1863 Diary, 14-5.
} 
moved away from the Republican Party, converting to the Democrats and voting for George Woodward in Pennsylvania's 1863 gubernatorial election. Not only did Swift change his political preference during the war, but he also hid his newfound political convictions from his old friends. ${ }^{104}$ The fact that Swift elected to hide his transition to the Democratic Party represents the most compelling aspect of his transformation. It is possible that local residents in Northampton County viewed Swift with disdain for leaving the Union Army so abruptly. Theodore Howell, also from Northampton County, responded to his wife's plea to resign and come home to their eight children, that "I think it would be to hot in old Allen for me to stop long, there has 2 captains resigned in the regiment and their men were very much put out about it and I have heard that when Capt Reimer came home his neighbors were very indignant [with] him for deserting his men."105 Although one was an officer and the other an enlisted soldier, Howell's story acknowledges that residents of Northampton County grew disgruntled at the resignation of one of their soldiers.

Swift's failure to share his political change of heart with friends, along with his descriptions of some local residents as "violent Abolitionists," highlights two other crucial factors of the loyalty debate. ${ }^{106}$ First, that at least on some level, Swift felt pressure to conform and feared an unspecified retaliation, perhaps social ostracism, from his friends. Furthermore, his secrecy and use of the word Abolitionist, reference the contentious atmosphere of eastern Pennsylvania politics and loyalty in the latter portion of the war. Swift never provided a concise reason for his transition from Republican to Democrat in 1863. His military service was obviously a key part of that transformation, but it seems, at least tangentially, that race and the

\footnotetext{
${ }^{104}$ Ibid., October 13, 1863.

${ }^{105}$ Howell, Letters, February 16, 1863.

${ }^{106}$ Swift, 1863 Diary, 24.
} 
Emancipation Proclamation influenced his decision. Not only did Swift present a clear disdain for Abolitionists, but he also had little love for African Americans. When conversing with a man in June of 1863, Swift recorded that their conversation turned to African Americans and that he favored allowing blacks into the army, an ironic, but malignant concession for an antiabolitionist. He "wished they would try them and kill off a few...enough whites have been killed... Negroes could be subtracted easier and their loss would not be felt." ${ }^{\prime 107}$ We can surmise that Swift disliked the prospects of freeing African American slaves, viewing such an action as clear evidence of disloyalty by the Republican Party.

There were other volunteers from Berks, Bucks, Lehigh, and Northampton counties that criticized the war but did not necessarily delve directly into the issue of loyalty, further complicating political and personal sentiments about the war. Unlike the soldiers who directly attacked Copperheads, the criticism from soldiers leveled at Republicans covered a more convoluted spectrum. With anti-Copperhead rhetoric, the discussions of men like Reichard and Frueauff had a clear, political target, that weaved together political preference and the issue of loyalty in their criticisms. Yet, there were also individuals like James Peifer, the oft-touted loyalty mapper, Copperhead criticizer, and Lincoln supporter, who spoke out against the war effort for a time. During the year and a half that Peifer spent recuperating in various Union Army hospitals throughout Maryland and Virginia, he wrote his sister, bitterly lamenting about his second stint in the Union Army. While confined to a hospital bed, Peifer came to see the North's leaders as generally poor candidates for their positions. They butchered soldiers for little gain and conducted an "unholy war" that brought destruction to the nation. He developed a strong

\footnotetext{
${ }^{107}$ Swift, 1863 Diary, June 2, 1863.
} 
desire to leave the Union Army and return home. ${ }^{108}$ Of course, Peifer was not alone in such sentiments. Other soldiers expressed similar complaints against the management of the war, shared a desire to return home to their loved ones, and complained about their service. ${ }^{109}$ Yet, such criticisms raise a conundrum: did a desire to return home or to critique the war represent disloyalty? Historians have established that during the Civil War soldiers from both the Union and Confederate armies grew weary of service, desiring to return home. ${ }^{110}$ Such criticisms therefore did not necessarily represent political condemnation of Lincoln or the war, but rather a basic right of soldiers who offered up their lives in defense of the nation to complain when military circumstances did not match their expectations. In other words, criticism of the war could take many forms, and unlike the Democrats or Republicans who attacked based on perceptions of loyalty and politics, other men spoke out against the war or their military service for personal reasons.

Peifer, along with Henry Hornbeck, complicates the use of loyalty, both in eastern Pennsylvania and historiographically. While Peifer criticized Copperheads as dangerous and disloyal, as previously mentioned, he also entered a stretch of significant criticism leveled at Union commanders and officials. ${ }^{111}$ Hornbeck similarly criticized the Lincoln Administration

\footnotetext{
${ }^{108}$ Peifer, Bethlehem Boy, January 3, 5, and 10, 1863, May 12, 1863, September 25, 1863, December 3, 1863. Peifer's complaints about the war remain limited to 1863 and his time in the hospital. It could be, that he was displeased at his confinement in a hospital bed and with extra free time on hand, lamented about what began as an unsuccessful year for the Union Army.

${ }^{109}$ Samuel G. Boone, to Emma April 11, 1863, Civil War Letters 1863-37, Historical Society of Berks County, Reading, Pennsylvania; Howell, Letters, February 16, 1863; Joseph N. Kemp, to wife May 18, 1862, Shanaman Collection, Historical Society of Berks County, Reading, Pennsylvania; William McMiller, to wife Rebeckah Beaufort March 25, 1864, Civil War Letters 1858-13, Historical Society of Berks County, Reading, Pennsylvania; Henry Miller, to Rebecca Miller September 11, 1864, Civil War Letters 1858-13, Historical Society of Berks County, Reading, Pennsylvania; Peifer, Bethlehem Boy, May 1, 1863.

${ }^{110}$ Reid Mitchell, Civil War Soldiers: Their Expectations and Their Experiences (New York: Viking, 1988), 50, 177-8; Reid Mitchell, The Vacant Chair: The Northern Soldier Leaves Home, (New York: Oxford University Press, 1993), 25-6; James I. Robertson, Soldiers Blue and Grey, (Columbia, SC: University of South Carolina Press, 1988), $102-4$.

${ }^{111}$ This period for Peifer began in January of 1863 and lasted until September of that same year.
} 
and its policies during the war. Yet, despite such criticisms, both men would go on to reenlist in the Union Army, Peifer for a third time in January 1864 and Hornbeck in clear disregard for his sister's requests not to reenlist, did so in February $1864 .{ }^{112}$ As a result of their complaints and then reenlistments, both volunteers complicate our understanding of loyalty during the war years. Peifer and Hornbeck were 'disloyal' to the standard of Republican newspaper editors who claimed that "an ardent and unquestioning support to the Administration" was a key component to loyalty, because both men criticized the administration. ${ }^{113}$ Despite their criticisms and 'disloyalty', these men continued to support the war effort by reenlisting, in effect challenging Democratic versions of loyalty because both men continued to serve a war that ultimately destroyed slavery and reworked the Constitution. ${ }^{114}$ Their actions should drive home the fact that loyalty was more than a broad category historians can use to label Northerners during the Civil War. Both men would have argued that they were loyal and their actions, both criticizing the government along with reenlisting in the Union Army provide examples that clash with either parties' wartime definitions of loyalty. The point here, without taking the discussion too far afield is to stress further the futility of defining one political group as loyal or disloyal during the Civil War. Peifer and Hornbeck are clear examples that loyalty was a complicated concept that historians cannot paint in black or white colors. ${ }^{115}$ Eastern Pennsylvania soldiers, whether it was

\footnotetext{
${ }^{112}$ Hornbeck, Diary, February 22, 1864; Mary Hornbeck, Letter to Henry Hornbeck, October 30, 1863; Peifer, Bethlehem Boy, January 31, 1864.

${ }^{113}$ Easton Free Press, September 4, 1862; Northampton County Journal, September 10, 1862.

${ }^{114}$ Peifer, Bethlehem Boy, November 7, 1864. As for Hornbeck, there is no indication in his diary of his voting preferences during any of the times that he served in the Union Army. He acknowledged receiving the "Democrat" referring to the Allentown Democrat, but he never provided commentary on what he received. Another curious aspect were the letters written to Henry while he served in the army. His family consistently inquired as to his political preference, but again without a response from Hornbeck himself, it is impossible to determine precisely what his political preferences were during the conflict.

${ }^{115}$ There are a noticeable dearth of Democratic soldiers populating the records of this thesis, something that is unavoidable for several reasons. On one hand, as the election results demonstrate in 1864, volunteers from eastern Pennsylvania voted heavily for Lincoln and the Republican Party (1864 Presidential Election: Berks-513 to 337; Bucks - 240 to 100; Lehigh-227 to 140; Northampton -228 to 132). It makes sense that with a preponderance of soldiers supporting Lincoln and his party, that proportionally the records available from volunteers would lean more
} 
Peifer, Hornbeck, or one of the other volunteers from the region showed the complexity of loyalty. They also support the notion that soldiers reformed their perception of loyalty from the early days of the war, incorporating political elements into their discourse.

Civilians, both the men who remained at home along with the women of eastern Pennsylvania, much like their counterparts who donned the Union blue, also exhibited a more virulent discussion about loyalty between 1863 and 1864. Although civilians at home left far fewer records than their friends and family in the military, their scant records coupled with the discussions carried on with loved ones in the Union Army, offer a concise picture of how civilians handled the concept of loyalty. While eastern Pennsylvanians still held war meetings and organized aid societies, their unifying sentiment evaporated. In the summer of 1863 , men and women in the region banded together to defend their state in June as Robert E. Lee invaded through the Cumberland Valley. They also organized meetings to raise bounties to encourage voluntary enlistment, while avoiding conscription. ${ }^{116}$ Despite these gatherings and demonstrations of mutual support, discord also grew on the homefront. As a result, civilians provided three new developments their discourse regarding loyalty. Ordinary men and women openly discussed the concept of loyalty with men in the army, they incorporated an intensified version of loyalty into a number of specific actions, and they revealed that sentiments about political loyalty affected their social experiences.

The responses of soldiers to their family members' questions revealed that civilians at home began to discuss loyalty with their loved ones serving with the Union Army. During the first year and a half of the war, most talk of loyalty originated from the soldier's perspective,

towards favoring Republican visions of loyalty. Furthermore, as Robert Sandow has indicated, wartime members of the Democratic Party also practiced "self-censorship" with their records. Sandow, Deserter Country, 11.

${ }^{116}$ Easton Argus, July 21, 1864; Easton Free Press, September 8, 1864; Easton Sentinel, July 2, 1863. 
placing their enlistment in terms of loyalty or mapping the perceived loyalty of people and places they encountered. Later in the war, the discussion traveled between the homefront and battlefront. When William Reichard responded to his sister, answering her question as to why Democratic editors were able to publish "treasonable" materials in March 1863, he revealed that his sister inquired about the subject of loyalty and that they shared perspectives on the subject. ${ }^{117}$ Similar inferences are possible when we take the discussions of soldiers, like Frueauff who agreed with his father that "Northern Secessionists" were the most severe threat to the nation. ${ }^{118}$ In line with the transformed discussion of loyalty, the fact that civilians also used a hostile approach to opposing political parties manifested itself in these discussions. Reichard's sister and Frueauff's father both felt that Democrats in eastern Pennsylvania were disloyal during the conflict. Thomas Jackson, the pro-Abolition, English rope maker joined in this discussion of intense, contentious loyalty. Jackson viewed the Confederates as "blood thirsty traitors" and disdained them and their institution of slavery greatly, but held no love for Northern Democrats either. ${ }^{119}$ Those "secret traitors north", or as he preferred "develocrats", assisted with the Confederate invasion of Pennsylvania in the summer of 1863 that ended at Gettysburg. ${ }^{120}$ Jackson had a clearly negative image of local Democrats and showered abuse down upon them

\footnotetext{
${ }^{117}$ Reichard's enlistment came towards the end of August 1862 and from the start he communicated frequently with his family, particularly with his siblings, his father, and brother-in-law. In regards to his communications with his family, a stark transition occurred. In the beginning of his service, he focused on his contentment with the patriotic displays of his fellow Allentoanians (September 22, 1862 and October 3, 1862), early in 1863 he transitioned to derisive discussions of loyalty and Democrats at home, predominately on January 31 , February 15,16 , and 26, March 9, 19, and 291863.

${ }^{118}$ Frueauff, Freddy's War, February 12, 1863.

119 Jackson was a fiery character. In the same letter that he painted the rebelling Southerners as traitors, he also explained to his cousin in England that "The history of the white man in America, is one long tale of terrible outrage \& murderous cruelty and oppression of other races of men. While constantly prating about his own patriotism, his great love of freedom \& his vast appreciation of his own rights he has been, in the mass, the bloodiest and most unprincebled despot, known in history." The rope maker did not mince words, he disdained slavery, believed that Southern rebels sought to destroy the nation, and that that nation was far from pure itself. Jackson, Letters, October $12,1862$.

${ }^{120}$ Jackson, Letters, August 20, 1863 and November 8, 1864. Again this also references the "paranoid style" of politics from Hofstadter.
} 
throughout the war, helping create a contentious atmosphere among the local populace. Other civilians, both men and women, provided their own commentary on loyalty exacerbated the fury of this debate.

Civilians also engaged this intense version of loyalty through a number of extra-textual actions. In May 1863, “A few patriotic ladies of Easton” left a homemade American flag and a note at the door of the Easton Sentinel's office, writing to Daniel Neiman that "We are pleased with the noble course you have pursued; endeavoring to preserve the Constitution and restore the Union as it once was." ${ }^{121}$ When those few "patriotic ladies" noted their thanks and support for the Sentinel's course of action, they entered into both the loyalty debate and the crisis over democracy. They simultaneously affirmed their affinity for Neiman's publications and noted that he was part of the Democratic (and legitimate) attempts to heal the nation. Compared to the flag given to John Dillinger by Mary Samuels and Emma Knauss earlier in the war, donating the flag to the Sentinel sent a clear political message that supported one specific party. Where Samuels and Knauss dedicated a flag to a regiment of soldiers, pushing that unifying concept of loyalty, the flag from the Easton women firmly supported the Democratic Party. Other women, such as Mary Hornbeck who refused to wave at a torch-light procession that brandished the image of Lincoln, but heartily waved at one for George McClellan in November 1864 or William Reichard's sister who inquired and discussed loyalty with her brother, demonstrate that attention to loyalty was pervasive. ${ }^{122}$ Mary Hornbeck, similar to the Easton women, clearly picked a side and demonstrated her loyalty, while Reichard's sister also implicated her preference. Together these women participated in a discussion about the use of loyalty. More important than gender inclusivity though, is the amount of attention paid to the notion of a more derisive form of

\footnotetext{
${ }^{121}$ Easton Sentinel, May 14, 1863.

${ }^{122}$ Mary Hornbeck to Henry Hornbeck, November 6, 1864; Reichard, Letter to Sister Sallie, March $29,1863$.
} 
loyalty during the later years of the Civil War. Men and women both focused intently on the issue of loyalty and revealed a contentious divide about the concept.

Nowhere was that contention more evident than in the effects that political division imparted on the social interactions of eastern Pennsylvanians. Division, not unity, came to rule experience in the streets. In Reading, the county seat of Berks County, the wartime environment became so hostile that the city's residents began to dissociate themselves from one another due to their partisan affiliation. John H. Rhoads informed his friend "Dear Doctor" on April 23, 1863, that on the preceding Tuesday evening a former minster, J. Clancy Jones, hosted a party at his house for city's residents. Yet, Rhoads and Reading's "Union folks," be they young or old failed to attend the ex-minister's party. Instead those "Union folks" attended the Grand Union Meeting held in the city that evening, which left Jones and the party organizers dispirited. The minister had made excessive preparations "to entertain their friends, but we can account for the absence of so many person, here it is - the Copperheads were there, and the Union people stayed away." ${ }^{123}$ Rhoads' letter indicated that political affiliation formed the foundation for social divisions within Reading. Despite his attention to the fact that Copperheads were present at the party, it is unclear if Rhoads considered Jones a Copperhead as well. When Rhoads, like newspaper editors and soldiers, referenced Copperheads, he invoked the idea of disloyalty, especially when he juxtaposed the concept to the "Union people." Rhoads implied that Copperheads were disloyal, while Unionists were implicitly loyal. The party hosted by J. Clancy Jones was not an isolated incident in eastern Pennsylvania. The fact that Beates Swift had to withhold his political sentiment from his friends in Northampton County revealed that at least some individuals feared revealing their political preference thereby avoiding censure or disdain

${ }^{123}$ John H. Rhoads to Dear Doctor, April 23, 1863. 
from their acquaintances. Combined with the partisan bickering, name-calling, and general animosity displayed through their discussions, the residents of Berks, Bucks, Lehigh, and Northampton counties highlighted the strained relationship between members of the opposing political parties.

Furthermore, the language used in their personal correspondences, whether it was from soldier or civilian, indicated the transition from a unified discourse about loyalty to a divisive and contentious use of the term. Unlike the first year and a half of the war, in late 1862 and throughout the next two years, men and women from Berks, Bucks, Lehigh, and Northampton Counties interjected terms such as traitor, loyal, or disloyal into their correspondences, outside of references to the Confederacy. They also implemented the use of derogatory nicknames, much like local newspaper editors did during the earlier part of the war. Republican or proadministration men and women targeted those who criticized the war effort as Northern Secessionists or Copperheads. ${ }^{124}$ Those individuals who voted Democratic and opposed the administration, such as Beates Swift, targeted their opponents as Abolitionists. ${ }^{125}$ This shift, the introduction of discourse about loyalty directed at other residents of eastern Pennsylvania as well as the application of derogatory nicknames, indicated an important change in the social and political climate. The topic of loyalty not only influenced what people from this region wrote about in their correspondences, it also came to signify how they viewed and identified their political opponents as a danger to the Union.

Where though did these men and women ultimately learn to use such derisive language about loyalty in the latter portion of the Civil War? Certainly, at the onset of the war they did not

${ }^{124}$ Clayton, to Friend Tip, October 20, 1864; Frueauff, Freddy's War, February 12, March 19, 28, April 12, May 16, 27 June 13, 1863; Reichard, Letters, March 26 and 29, 1863; Rhoads, Letter to Dr. March 30, 1863.

${ }_{125}$ GW Kramer to Henry Hornbeck, May 7, 1863; Mary Hornbeck to Henry Hornbeck, November 6, 1864; Swift, Diary, December 1862 and May 2, 1863. 
view loyalty in such contentious terms, though their local newspaper editors did. While it is difficult to prove the effect local newspaper editors had on eastern Pennsylvania's population and the concept of loyalty, they did play a part. Many residents read the local papers. Even the men in the field, through the charity of loved ones or local aid societies, remained tethered to the papers. Eastern Pennsylvanians also discussed the contents of the papers they received from back home or acknowledged their receipt of the papers. ${ }^{126}$ Even Mary Hornbeck provided commentary on the papers, noting that their debates were "shameful, calling each other liars and everything." 127

Yet, did such statements reveal how deeply the editors and their publications influenced the thinking of these men and women? Superficially, they did, but with a lack of clear introspection by letter and diary writers, such assessments are only tenuous at best. Patterns did develop though. It was around March 1863 that Republican editors began to use the term Copperhead as a means of describing anti-war Democrats. Soldiers and civilians began to use that term around the same time. It is possible that the soldiers garnered this information from other soldiers they served with, yet it is equally likely that local papers also influenced the introduction of this language into their discourse. Regardless, the fact of the matter is that newspaper editors played a role in the development of the loyalty debate, at least prompting the response of soldiers in Reichard's regiment to pass resolutions against Democratic publications. $^{128}$

\footnotetext{
${ }^{126}$ George Flack, Diaries, Bucks County Historical Society, Doylestown, Pennsylvania, April 20, July 6, 1862, January 16, March 22, 27, May 8, 1863;Frueauff, Freddy's War, November 13, 1862, January 17, 25, 1863, March 19, 1863; Melick, Diary, March 10, 11, 1863; Peifer, Bethlehem Boy, October 16, 1861, Reichard, Letters, January 31, February 15, 16, 26, March 28, 29, and April 19, 1863.

${ }_{127}$ Mary Hornbeck to Henry, October 8, 1863.

${ }^{128}$ Reichard, Letters, April 19 and 26, 1863.
} 
Editors also continued to delve into the realm of personal criticisms leveled at other editors. In 1863, Enos Pinzer wrote to his Bucks County counterpart, Colonel William H. Davis, owner of the Doylestown Democrat and acting commander of the 104th Pennsylvania Volunteer Infantry Regiment. In his letter, Pinzer suggested that Davis return home and wrest control of the Democrat back from J.D. Mendenhall, who ran the paper in Davis' absence. He also subtly implied that Davis could not adequately prove his loyalty to the nation when he was not at home controlling the publications of his paper. ${ }^{129}$ Throughout the war, Pinzer criticized the Democrat, but attempted to maintain a cordial relationship with Davis, minimalizing his attacks on the paper's proprietor, instead aiming his accusations of disloyalty at the paper's current editor, J. D. Mendenhall. ${ }^{130}$ On November 24, 1863, Davis published his reply to Pinzer, declining to return home to retake control of his paper. Instead, Davis revealed that he saw his Republican counterpart as "not only my political, but personal enemy, for your persistent warfare upon me." ${ }^{131}$ Evidently, Davis did not believe that Pinzer had kept his criticisms cordial. Instead of returning home to take back the Democrat from his replacement (Davis still owned the paper, though he no longer controlled the weekly publications), Davis offered "deeds in evidence of my loyalty. I have shown my willingness to shed my blood in the cause, while you have, so far, only shed bottles of ink." ${ }^{, 132}$ He urged Pinzer to enlist, matching his own deeds with equal deeds of action. The exchange between Pinzer and Davis highlighted the divide spurned by the discussion of loyalty, as well as the continued conflict between newspaper editors over what it meant to be a loyal American in the midst of the Civil War. Davis' reply also returned to the most basic

\footnotetext{
${ }^{129}$ Doylestown Democrat, November 24, 1863.

${ }^{130}$ Early in the war, Pinzer made specific attempts to exclude Colonel Davis from his criticisms of Democrats and their local mouthpiece. Bucks County Intelligencer, July 2, 1861, October 8, 1861, June 17, 1862, and July 1, 1862. Around July 15, 1862, however Pinzer and his Intelligencer became more critical of Davis, pleading with him to return and take control of paper.

${ }^{131}$ Doylestown Democrat, November 24, 1863.

${ }^{132}$ Doylestown Democrat, November 24, 1863.
} 
foundation of loyalty throughout the war: that nonpartisan action, in this case military service, was essential. However, eastern Pennsylvanians constantly acted along partisan lines because they saw their version of loyalty as the only correct one to guide the nation to a successful conclusion.

Davis' service and his exchange with Pinzer not only highlighted the continued and often personal discord that accompanied the discussion of loyalty among local newspaper editors. That exchange also raised the subject of War-Democrats, the members of the Democratic Party who strongly supported the war effort, but also resisted some of Lincoln's more liberal policies, such as Emancipation and the restriction of civil liberties. ${ }^{133}$ Very little scholarly work has come forth over the past four decades on the subject of these Democrats caught between political parties. Christopher Dell's Lincoln and the War Democrats from 1975 serves as the scholarly treatment of War Democrats. In that monograph, Dell provided a top-heavy political history, examining politicians and generals he identified as War Democrats. Dell argued that these men played a major role in shaping Lincoln's wartime policy and helped soften conservative American traditions because of their support for the war effort and acceptance of wartime policies. ${ }^{134}$ While Dell's conclusions placed great, perhaps extravagant, claims on the importance of War Democrats, the issue of this political and historiographic anomaly raise important considerations about the slipperiness of wartime loyalty. Davis was certainly a War Democrat, he enlisted,

\footnotetext{
${ }^{133}$ The extent to which Lincoln actually infringed upon civil liberties is a continually contested subject in the historiography. In The Fate of Liberty, Mark Neely advocated that while the number of arrests made by Lincoln were significantly higher than previous estimates suggested, most of those arrests consisted of individuals from the South. Lincoln did bend some freedoms during the war effort, something that eastern Pennsylvania Democrats happily pointed out during the war. Mark Neely, The Fate of Liberty: Abraham Lincoln and Civil Liberties, (New York: Oxford University Press, 1991), xvi, 75-7, 86-7, 93-6, 103-4, 138-40, 173, 204. For discussion about War Democrats: Christopher Dell, Lincoln and the War Democrats: The Grand Erosion of Conservative Tradition. (Cranbury, New Jersey: Associated University Press, 1975), 11; Gallagher, The Union War, 5; J. Matthew Gallman, The North Fights the Civil War: The Home Front, (Chicago: Ivan R. Dee, 1994); 49, 143; Guelzo, Fateful Lightning, 314, 524; Paludan, A People's Contest, 234-5, 247; Weber, Copperheads, 1, 16, 33, 82, 122-3, 179-80, 180, 184, 203.

${ }^{134}$ Dell, Lincoln and the War Democrats, 8-11, 145, 152, 245-7.
} 
fought the Confederacy, but remained a proponent of the Democrat Party. But what about men like Henry Hornbeck, who while a Democrat that criticized the war, remained in the Union Army from 1862 to 1865 ? How do we classify Democratic newspaper editors who professed that they wanted to subdue the South, but demanded that their party was the only organization capable of doing so successfully? ${ }^{135}$ In part because the lines are so difficult to parse out, between the various portions of the Democratic Party, this text focuses only on the larger notion of Democrats. However, the shades of grey that stand between a Democrat and a War Democrat, especially in terms of loyalty should reinforce the need to view loyalty as a less stringent and more flexible concept.

Editors however continued to portray loyalty as a concrete concept based on one's partisan affiliation, but like soldiers and civilians in 1863 and 1864, these editors also increased the virulence of their loyalty rhetoric. Of course, editors still defended their own party's loyalty, while simultaneously continuing the accusations and criticisms of disloyalty from the earliest days of the war. From the autumn of 1862 until the conclusion of 1864's Presidential Election, they relied on undermining their opponent's definitions of loyalty through derogatory nicknames intended to invoke suspicion of disloyalty (Copperhead, Northern Secessionists, or Abolitionists), attacks directly accusing political opponents of disloyalty, and conflating political opponents with secessionism.

There were of course new wrinkles to the editors' attacks. As evidenced by the local volunteers and citizenry, Republican editors introduced the term Copperheads. ${ }^{136}$ During the

\footnotetext{
${ }^{135}$ As we will see, this theme becomes crucial to the crisis for democracy, as Democratic and Republican editors attempt to portray their opponents as incapable of reunifying the nation.

${ }^{136}$ References to the term Copperhead appeared in eastern Pennsylvania around early March, 1863. McPherson acknowledges that the concept originated in 1861 and gained larger acceptance come the fall elections of 1862, but
} 
early part of 1863 , J. P. Heitrich equated the venom of copperhead snakes, as previously mentioned to that of his Democratic opponents. ${ }^{137}$ In response, Daniel H. Neiman of the Easton Sentinel and William Hutter of the Easton Argus unleashed their editorial titled "Copperheads vs Blacksnakes", where both editors attempted to vindicate the nickname Copperhead by creating an allegory between Copperhead snakes and Democrats, while they labeled Republicans as disloyal "Blacksnakes." ${ }^{\prime 138}$ Neiman and Hutter's endorsement of the Copperhead label was much more than a clever turn of phrase. It was an attempt to legitimize the Copperhead nickname, undermining the potential harm of the Republican moniker, while simultaneously creating a diminutive for Republicans. Ultimately, the "Blacksnakes" label failed to catch on in eastern Pennsylvania, never appearing again as a viable moniker for Republicans in the region. In comparison, the Copperhead label against Democrats maintained its presence throughout the North during the war, as well as in the annals of history, as many historians still remember wartime Democrats as Copperheads. Despite the failure of the "Blacksnake" label to catch on, the attempt to reorient the Copperhead nickname revealed several important items about the debate over loyalty. First, that the nicknames used to imply disloyalty held a good deal of influence, hence the attempt to unravel the Copperhead label. Second, that the issue of loyalty permeated deeply throughout the region as editors attempted to rework nicknames to their advantage.

The fascination with a snake-based allegory also presented another compelling undertone to the loyalty debate in eastern Pennsylvania. Historians have widely discussed the fact that Republicans labeled anti-war Democrats as Copperheads. Jennifer Weber's most recent

\footnotetext{
in eastern Pennsylvania the term did not appear until March 1863. Easton Free Press, March 5, 1863; Northampton County Journal, March 4, 1863.

${ }^{137}$ Northampton County Journal, March 4, 1863.

${ }^{138}$ Easton Argus, April 2, 1863; Easton Sentinel, March 26, 1863.
} 
monograph is titled Copperheads: The Rise and Fall of Lincoln's Opponents in the North, Frank Klement wrote Copperheads in the Middle West, along with a number of other historians who frequently described wartime, anti-Lincoln Democrats as Copperheads. ${ }^{139}$ Yet the traditional origin story of this nickname in McPherson's Battle Cry of Freedom, and the accepted narrative in general, attributed the name to Ohio Republicans in 1861. Later, during the fall elections in 1862, McPherson noted that a wider array of Republicans implemented use of the Copperhead nickname to malign Democrats. In response some resilient members of the Democracy, like Neiman and Hutter, tried to regain control of the label as a means to undermine "Republican "tyranny,"” but failed to do so as the name gained further acclaim amongst Republicans. ${ }^{140}$ While McPherson relegated his description of the "Copperhead" origin story to a footnote, a cultural approach should question why Republicans picked that specific term and why the two Easton Democrats responded by positing Republicans as "Blacksnakes."

Considering a deeper meaning to the imagery of snakes calls upon an early American and biblical experiences that painted snakes as emblems of original sin. Thomas Slaughter aptly outlined the history of the snake's malevolence in his reevaluation of Lewis and Clark's exploration of the Northwest. Americans, Slaughter maintained, early in the nineteenth century, saw snakes as the embodiment of Satan, capable of ensnaring human souls, and as violent, destructive creatures. Although by the middle of the century Slaughter noted the Puritan inspired vision of demonic snakes faded away, fear and distrust of the serpents remained present in

\footnotetext{
${ }^{139}$ David Blight, Race and Reunion: The Civil War in American Memory, (Cambridge: Harvard University Press), 52, 137; Paul Cimbala, Soldiers North and South: The Everyday Experience of the Men Who Fought America's Civil War, (New York: Fordham University Press, 2008), 108; Gallagher, The Union War, 5, 63-4, 93 102, 104-5, 107-8; Guelzo, Fateful Lightening, 228; Klement, Copperheads in the Middle West; Mitchell, Civil War Soldiers, 86-7; McPherson, Battle Cry of Freedom, 494; Weber, Copperheads. As an added note, Blight's Race and Reunion, specifically noted that when James A. Garfield fought with Democrat William E. Fink, the eventual President called Fink a Copperhead. Blight wrote that Fink's "wartime loyalties had followed him into Reconstruction," implying a singular definition of Copperhead loyalty.

${ }^{140}$ McPherson, Battle Cry of Freedom, 494.
} 
American society. ${ }^{141}$ With such a rich background, both religious and environmentally, it is probable that Republicans, at least subconsciously, drew on the shared history and concern of snakes to hamper the Democratic Party. Their aim then was to use the Copperhead name, not only to portray a specific group as disloyal, but also to illicit the long-held fear over snakes in American history. Hutter and Neiman's "Blacksnake" rebuttal attempted to latch on to those deep-seated fears in response. Much like the concept of original sin, eastern Pennsylvanian editors' used snake-like imagery to describe their opponents as destructive agents, but in this case political opponents threatened to destroy the nation, a political Eden. As we have witnessed, editors, followed by soldiers and civilians used nicknames to imply disloyalty, but historians rarely probed why they implemented those specific nicknames. Considering the deeper history of snakes in American culture can at least provide us with a potential answer on that score. ${ }^{142}$

The same line of inquiry makes sense when considering the Abolitionist nickname used by Democrats to target local Republicans. Instead of calling on environmental or religious subjects, Democrats turned to the subject of race to target their opponents. The use of the term Abolitionist by editors, soldiers, or civilians, attempted to create the feeling that Republicans sought to overturn the accepted racial norms, freeing slaves, giving them the right to vote, and making African-Americans equal to white Americans. ${ }^{143}$ Democrats used the Abolitionist label to portray Republicans as more interested in freeing slaves than in restoring the Union. ${ }^{144}$ At the

\footnotetext{
${ }^{141}$ Thomas P. Slaughter, Exploring Lewis and Clark: Reflections on Men and Wilderness. (Vintage Books: New York, 2003), 65-83.

${ }^{142}$ Keith Thomas' Man and the Natural World, provided a similar discussion of snakes at least for the people of England between 1500-1800. Keith Thomas, Man and the Natural World: Changing Attitudes in England 15001800, (Oxford: Oxford University Press, 1983), 64, 69, 74.

${ }^{143}$ Doylestown Democrat, June 2, July 7, August 25, September 22, November 3, 1863, March 1, 1864; Easton Argus February 26, March 12, September 10, October 8, 1863, January 7, 21, March 17, October 6, 1864; Easton Sentinel, December 11, 1862, October 1, December 17, 1863, August 4, 1864; Reading Gazette and Democrat, March 7, 14, August 1, 8, 1863, February 20, 1864.

${ }^{144}$ To counter this, nationally Republicans operated as the Union Party during the war-Lincoln even ran as a Union Party candidate in 1864's Presidential Election. However, in eastern Pennsylvania, while Republicans did nominally
} 
same time, editors also recalled the horrors of the Haitian Revolution from the turn of the nineteenth-century to illicit the fear of revolt, chaos, and death if Republicans freed Southern slaves. Ashli White and Edward Rugemer have both shown that during the nineteenth century Americans viewed Haiti with apprehension, fearing that similar events would transpire in the United States if the South relinquished the institution of slavery. ${ }^{145}$ After the announcement of emancipation, Democrats increased their use of Abolitionists connected to the troubled memory of the Haitian Revolution and the constant fear that Republicans meant to make freed slaves the political and social equal to white Americans. ${ }^{146}$ Nicknames therefore were a means of engendering the sentiment of disloyalty through fear, a clear indication that the discussion of loyalty was more intense during 1863 and 1864. Abolition and Copperhead monikers pulled on shared American experiences that made white Americans feel uncomfortable, whether it was about a slippery serpent or racial change.

change their name to the Union Party, because of strong Democratic influence and electoral majorities, the idea of a Union Party never gained much ground.

${ }^{145}$ Edward Bartlett Rugemer, The Problem of Emancipation: The Caribbean Roots of the American Civil War, (Baton Rouge: Louisiana State University Press, 2008); Ashli White, Encountering Revolution: Haiti and the Making of the Early Republic, (Baltimore: The John Hopkins University Press, 2010).

${ }^{146}$ It is hard to get a clear gauge on eastern Pennsylvania's racial sentiments, despite the back and forth over slavery and emancipation in the local papers. Chandra Manning has noted that for many soldiers in the Union Army, their experiences in the South represented their first, real face-to-face confrontation with slavery. The result, she argued, was an increased desire amongst Northerners to destroy the institution, a sentiment that they shared with their friends and family back home. However, amongst the correspondences of eastern Pennsylvania soldiers the discussion of slavery appears rather infrequently. There were some soldiers who discussed the institution of slavery, such as Phillip Melick, John Freauff, and Reading resident Thomas Jackson, but most soldiers or civilians did not discuss slavery. Soldiers often made references to slaves they encountered, either through a range of racial slurs or through statements like that of Joseph Kemp to his wife Sarah, when he asked her to tell their daughter "I would bring a little nigar boy for her if she wants one his name shall be Snowball." Such statements though reflect more casual references to African-Americans, rather than insightful or retrospective comments about the institution. It is possible to suggest that such a death of discussion challenges Manning's findings, but the source base here is too small to do so in any substantive way. However, the records do demonstrate that outside of the politicized debates in newspapers, the institution of slavery factored into the discourse of the Civil War in a minimal way amongst local residents. Leslie M. Harris, In the Shadow of Slavery: African Americans in New York City, 1626-1863 (Chicago: University of Chicago Press, 2003), 189; Kantrowitz, More Than Freedom, 57-8; Jackson, Letters, October 12, 1862, August 20, 1863, April 18, 1864, Joseph N. Kemp, Letters, April 1, 1862. (LC01 Shanaman Collection, Box 1, Folder 5; The Historical Society of Berks County, Reading, Pennsylvania); Melick, Diary, June 11, 1863; Peifer, Bethlehem Boy, January 18, 1863; Varon, Disunion, 84-5, 133, 190-1, 221. 
Regardless of the continued attacks between newspaper editors, their use of nicknames, or criticisms of their political opponents, loyalty remained a constant subject for editors to use. Through this continued debate over loyalty, newspaper editors maintained the crisis of democracy that pitted Democrats and Republicans against one another. Editors continued to paint their opponents as enemies that presented an equal, if not greater, threat to the nation than the Southern Rebels. 1863 and 1864 presented the perfect atmosphere for the foundations of democratic crisis to come to fruition. Residents of eastern Pennsylvania witnessed two significant elections in those years, the 1863 Gubernatorial Election that pitted incumbent Republican Andrew Curtin against Pennsylvania State Supreme Court Judge George Woodward and the 1864 Presidential Election between Abraham Lincoln and Democratic candidate George McClellan. Both elections played out statistically in a very similar fashion, with Democratic candidates (Woodward and McClellan) receiving majorities in all four counties, ranging from as small as about a thousand in Bucks County to nearly six times that number in Berks County, for both campaigns. ${ }^{147}$ In the broadest sense regarding the issue of loyalty, the election results are less important than the ways in which soldiers, civilians, and newspaper editors invoked the idea of loyalty during the elections. Loyalty, and the threat posed by the perceived disloyalty of political opponents became the hallmark of the crisis of democracy. Essentially, the democratic process, a concept quintessentially American, represented the vehicle through which the nation could be saved or destroyed, depending on the election of one party, one definition of loyalty, over another.

This presentation of the Gubernatorial and Presidential elections as keys to the nation's preservation was common among members of both parties and signified one of the fundamental

\footnotetext{
147 Shankman, The Pennsylvania Antiwar Movement, 135-6; Bucks County Intelligencer, October 27, 1863; Doylestown Democrat, October 27, 1863; Reading Gazette and Democrat, October 17, 1863.
} 
tenets that ran through both campaigns. Editors, soldiers, and civilians all shared an apocalyptic sentiment, lending their voices to political campaigns and the crisis for democracy. Local editors remained the most prominent advocates for the Union's survival or destruction in the 1863 and 1864 elections. Democratic editors painted the political contests as a battle between Abolitionists who sought to destroy the Constitution, along with slavery, elevating the African American to heights equal of white men, against the pure sons of Jefferson who sought to uphold the Constitution. "The Democratic Party must gain power," in October to "unite what fanaticism has disunited - to heal the deep cut thrust by Abolition traitors," Mendenhall noted in September 1863. ${ }^{148}$ After Democrats failed to elect Woodward to the governorship of the Keystone State, local editors sounded the alarm much like Hutter and his Argus, who identified the Presidential Election as the deciding factor in "the fate of the Union, the continuance or discontinuance of constitutional government, and, consequently, the weal or woe of thirty millions of free men." 149 Democratic editors saw Curtin, Lincoln, and other Abolitionists as a clear threat to the Union war effort and the restoration of the nation. ${ }^{150}$

Republican editors sounded a similar tune, but reversed the roles of the parties. Lewis Gordon placed great important on Curtin's reelection in the fall of 1863, arguing that "On its result, in fact, the question of whether we shall be a free people... whether we shall be one nation or not" rests. ${ }^{151}$ Likewise, even with Curtin's success and return to office, the reelection of Lincoln the following year was just as important. On the day of the election, Pinzer argued that "The day has dawned which is to witness the greatest civil conflict of the country; which is to

\footnotetext{
${ }_{148}^{14}$ Doylestown Democrat, September 29, 1863.

${ }^{149}$ Easton Argus, February 4, 1864.

${ }^{150}$ Easton Argus, October 9, 1862, February 26, March 5, May 7, June 25, 1863, February 4, 1864, October 6, 1864; Easton Sentinel, January 8, July 9, October 8, December 17, 1863, May 16, October 18, September 8, 1864; Doylestown Democrat, June 23, September 22, 29, November 3, 1863, March 1, 1864; Reading Gazette and Democrat, November 13, 1862, January 24, August 1, 1863, March 12, September 24, 1864.

${ }^{151}$ Easton Free Press, August 27, 1863.
} 
determine whether the Union is to be preserved and the nation to triumph over faction and treason, or whether we shall submit in disgrace to the traitors of the South, and surrender to them forever every hope of human freedom." ${ }^{, 152}$ For Republican editors, just like their Democratic counterparts, both elections were extremely important, in their eyes, to the preservation of the Union. ${ }^{153}$ Men like Gordon, Pinzer, and other local editors continued to embed the language of loyalty into the discourse of political elections. It was "Abolition traitors" that damaged the nation or the failure to reelect Lincoln that would lead to the triumph of "traitors of the South." In both instances editors they either directly addressed their loyalty or implicated the opposition as traitors. They created a rather ironic moment with their use of loyalty amongst the elections. At one point, Democratic and Republican editors created a crisis of democracy, because their disloyal opponents stood to gain power from electoral success, but that same process that gave disloyal elements the hope of success, was the only means to head off the collapse of the Union war effort.

Soldiers and civilians echoed the same belief that the elections of 1863 and 1864 were both essential for the fate of the Union. Ordinary men and women commented less frequently on the importance of the elections in comparison to local editors. Yet, the residents of eastern Pennsylvania also made it clear they saw both elections in stark terms. For the gubernatorial contest a letter from a soldier labeled only as JDT appeared in the Doylestown Democrat, writing that "I hope and pray to God that the Democratic party may carry the day, for that is the only hope and salvation of our country." "154 Likewise, a letter from J. Kempfer noted that "If Abraham

\footnotetext{
${ }^{152}$ Bucks County Intelligencer, 8, 1864.

${ }^{153}$ Bucks County Intelligencer, September 1, 8, 22, 1863, September 6, 13, November 8, 15, 1864; Berks and Schuylkill Journal, October 3, 1863, November 5, 1864; Easton Free Press, February 2, August 27, October 8, 1863, January 1, September 29, 1864; Northampton County Journal, March 11, 25, October 7, 14, 1863, March 2, April 20, June 22, August 31, 1864.

${ }^{154}$ Doylestown Democrat, September 22, 1863.
} 
Lincoln is elected we will conquer the South, for if they see that we stand united and are bound to fight it out they will give in. But as sure as the North elects a Peace President our country is ruined." 155 These comments from the men at the battlefront, acknowledge the fact that the contention and perceived peril of the election extended beyond the confines of local papers. ${ }^{156}$ Civilians such as Thomas Jackson also added to this sentiment when he noted that the Presidential Election was not just a vote for one office, but for also "whether there is, or ever will be again, a united states or not." ${ }^{, 157}$ Jackson, like the soldiers, believed the political contest was fraught with dire consequences, a literal depiction of good and evil. The key point to take away from the editors' discussions and that of local soldiers and civilians is that the imagery of a crisis for democracy existed at all levels of correspondence and society. Both residents and newspaper editors, both explicitly and implicitly, depicted elections in 1863 and 1864 as serious challenges to the restoration of the Union.

This discourse quite clearly demonstrated the fact that competing definitions of loyalty divided the political sentiments of eastern Pennsylvanians during both elections. It also revealed how men and women viewed the prospects of American democracy as tensions mounted and politics grew more divisive. Through an examination of loyalty in eastern Pennsylvania, we encounter a rather different form of democracy than in Mary Ryan's Civic Wars. Ryan argued that violence became a staple of democracy around the middle of the nineteenth century, with

\footnotetext{
${ }^{155}$ Easton Free Press, September 29, 1864. Kempfer, from what the records reveal served in the 67th Pennsylvania, but was from Schuylkill County. He served though with soldiers from Northampton County. The appearance then of his letter in a Northampton County paper, service with local soldiers, and the fact that his comment sheds light that the crisis over democracy did not appear just in these four eastern Pennsylvania counties, warranted its inclusion. Furthermore, Schuylkill County borders Berks County, therefore it was geographically close to the debates that raged in eastern Pennsylvania.

${ }^{156}$ Bucks County Intelligencer, September 15, 1863; Berks and Schuylkill Journal, October 1, 1864; Easton Free Press, September 29, 1864; Easton Sentinel, January 8, March 12, 1863; Peifer, Bethlehem Boy, November 7, 1864; Reading Gazette and Democrat, October 3, 1863, September 24, 1864.

${ }^{157}$ Jackson, Letters, November 8, 1864.
} 
people clashing over the definition of the "public" and participation in the democratic process. ${ }^{158}$ During the Civil War in eastern Pennsylvania loyalty, politics, and democracy coalesced in a different fashion. Democracy in many ways became a double-edged sword. It could cut one way with the election of one's own political faction, ushering in the end of the rebellion and the restoration of the nation. Yet, the election of political adversaries could also cut the other way, dooming the hopes of peace and restoration. Eastern Pennsylvanians emulated the violence of Civic Wars in a war of words against their opponents, but also spoke to a greater peril they perceived working its way through the political process, the election of their opponents to office in the context of the war.

Regardless of who pitched the idea about an election's importance or their contributions to the crisis for American democracy, they continually positioned loyalty at the center of these conversations. Political opponents amidst the crisis were traitors, either to the Constitution, freedom, or more importantly, reunifying the fractured United States. When individuals in eastern Pennsylvania generated the image that their political opponents opposed reunification or the Constitution, they painted them as disloyal, juxtaposing the author's party as both loyal and the logical solution to the threat presented by their opponents. While loyalty remained the foundation of the crisis over democracy in 1863 and 1864, eastern Pennsylvanians also interjected the concept in other ways, which reveal the contention over the concept and in political elections.

Democratic newspaper editors in eastern Pennsylvania in 1863 and 1864 attempted to curtail the use of concepts such as loyalty and traitor amongst the regional populace. Despite their electoral successes in Berks, Bucks, Lehigh, and Northampton counties, as well as

\footnotetext{
${ }^{158}$ Ryan, Civic Wars, 5-18 and 136-179.
} 
throughout much of eastern Pennsylvania in 1863 and 1864, the loyalty debate seemingly began to frustrate local Democrats. ${ }^{159}$ On several occasions, Democratic editors attempted to remove or at least lessen the importance of the term loyalty in the discourse of wartime politics. The Easton Argus and the Doylestown Democrat highlighted the fact that the use of loyalty referred to aristocratic and monarchal tendencies. The term loyalty, Hutter argued, "has no proper or significant meaning as applied to American citizens," instead the term loyalty only applied to monarchies, with their kings and queens, whereas patriotism was a "co-relative term" with "free government. ${ }^{" 160}$ Similarly, J. D. Mendenhall of the Doylestown Democrat urged readers that the term traitor was only a valid criticism of individuals "when a man takes arms into his hands against lawfully constituted rulers." ${ }^{, 161}$ Both of their responses attempted to remove the power of Republican accusations that they were disloyal. Historians have noted that Democrats were at a decided disadvantage during the Civil War, because Republicans controlled access to much of the governmental infrastructure, power to hand out patronage positions, and presented their organization as the wartime Union Party. ${ }^{162}$ Democratic editors' attempts to undermine the concept of what the terms loyalty and disloyalty meant that they could counter a strong tool in the Republican arsenal. ${ }^{163}$ In Reading, the city's mayor reportedly outlawed the use of nicknames, such as Copperhead or other politicized nicknames in the summer of $1863 .{ }^{164}$ Jackson's acknowledgement that local Democrats wanted to remove the use of derogatory

\footnotetext{
${ }^{159}$ Shankman, The Pennsylvania Antiwar Movement, 135-6, 199-200. In both elections the counties of Berks, Bucks, Carbon, Lehigh, Luzerne, Monroe, Montgomery, Northampton, Pike, Schuylkill, and Wayne in eastern Pennsylvania voted for the Democratic candidates Woodward and McClellan. However, back in 1860 the results were more evenly divided. Bucks, Carbon, Lehigh, Luzerne, Montgomery, Schuylkill, and Wayne voted for Lincoln, while Berks, Monroe, Northampton, and Pike threw their support behind the Democratic fusion ticket.

${ }^{160}$ Easton Argus, May 19, 1864.

${ }^{161}$ Doylestown Democrat, January 12, 1864.

${ }^{162}$ Smith, No Party Now, particularly chapter 4.

${ }^{163}$ Easton Argus, May 19, 1864; Easton Sentinel, January 1, 1864; Doylestown Democrat, September 22, 1863 and January 12, 1864.

${ }^{164}$ Thomas Jackson, Letters, August 20, 1863.
} 
nicknames from use in town highlights their desire to remove loyalty from the discourse of wartime politics. Such a sentiment reinforces the importance of loyalty, and at least for Democrats, the power of the criticisms against them, during the Civil War.

Jackson's revelation however is also an indication of the underlying irony that ran throughout the discourse of loyalty. Democrats often criticized the Lincoln administration and other local editors for the restriction of free speech in public or in their local newspapers. One of the most significant events Democratic editors targeted was the arrest of Clement Vallandigham, the outspoken, anti-war Senator from Ohio. After a speech at Mount Vernon, Ohio where Vallandigham intentionally lambasted the war as a tool to free slaves and sacrifice American liberties, General Ambrose Burnside placed Vallandigham under arrest. ${ }^{165}$ Neiman captured the sentiments of local Democrats as he criticized Republicans for falling to sustain free speech during the war. ${ }^{166}$ In this light, the attempt to eliminate the Copperhead label in Reading and the discussion of loyalty throughout eastern Pennsylvania was deeply ironic. Editors for the local Democratic papers demanded the right to free speech, but only insofar as it helped them. Once Republicans began to wield the hammer of loyalty and the associated nicknames, like Copperheads, Democrats attempted to curtail the use of that language.

In addition to attempts to curtail the language of loyalty, accusations of electoral fraud also appeared in the papers of eastern Pennsylvania editors from both parties. In the aftermath of defeat, local editors criticized their opponents of cheating to gain victory. Locally, Democratic editors found little reason to complain, consistently sweeping away their Republican opponents. Yet, they did find room to complain about larger state and national elections, arguing that

\footnotetext{
${ }^{165}$ McPherson, Battle Cry of Freedom, 596-7.

${ }^{166}$ Easton Sentinel, May 14, 1863. Unfortunately the commentary on Vallandigham's arrest is sparse from the records of local Democratic papers. The Reading Gazette and Democrat is missing issue that cover much of early 1863 and the Doylestown Democrat's pages for May and June of 1863 are completely illegible.
} 
Republicans used fraud and intimidation to thwart the proper election of Democratic candidates. ${ }^{167}$ Republican editors likewise focused on electoral defeats on the local level. ${ }^{168}$ Although these accusations of fraud appeared following elections in small numbers, the fact that the editors published them at all pushes the notion of disloyalty and democratic crisis to the front of the election cycle. Here, the crisis took on a new form, the perception that Democrats and Republicans abused the democratic process. Editors implied that such actions were anathema to core American principles, such as the right to vote, and therefore their political opponents were disloyal.

Attempts to discredit the language of loyalty or the accusations of electoral fraud extends the idea that loyalty was a complicated concept that permeated much of eastern Pennsylvania's Civil War society. Throughout the third and fourth years of the war, loyalty as evidenced above, took on a significantly more politicized and derisive context. Gone were the days when Democrats, Republicans, soldiers, and civilians advocated for a united sense of loyalty. The development of a crisis of democracy was an accidental development of their desire for unity based on their definitions of loyalty and their desire to secure electoral victory. Editors positioned their opponents as disloyal elements, which in turn created a crisis in the democratic process. The antagonism and fear about the possible election of political opponents was an unintentional extension of the loyalty debates. At the beginning of the war, soldiers, civilians, and newspaper editors positioned loyalty in a dichotomy where antipartisan unity represented loyalty and partisanship or support of the Confederacy as disloyal. But the definitions of loyalty produced by newspaper editors remained politically based at their core-either unconditional

\footnotetext{
${ }^{167}$ Easton Argus, October 22, 1863; Read Gazette and Democrat, October 17, 1863; Easton Sentinel, October 15, 1863 , November 17, 1864.

${ }^{168}$ Easton Free Press, October 15, 1863; Northampton County Journal, November 4, 1863.
} 
support for Lincoln's handling of the war or a strictly limited interpretation of the war effort. As individuals failed to adhere to their opponent's definition of loyalty, unity cracked. In its place this crisis of democracy appeared in an environment already rich with division between the Union and Confederacy. What followed was the belief for eastern Pennsylvanians that their political opponents represented a threat to the survival of the nation. As such loyalty continued to inform, at least perceptually, how eastern Pennsylvanians viewed who were "true" Americans during the Civil War. Political preference and the definition of loyalty one adhered to defined how local residents viewed inclusion in the idea of the nation. If a man or woman expressed a similar version of loyalty, they were "true Union men" (or women). But if they did not share the same political and loyalty-based identities, they were traitors to the nation, equal to the Confederates, and opposed to the true principles of being an American. Perceptions of loyalty informed these sentiments among the local populace. By assuming that their political opponents were disloyal traitors threatening to destroy the nation, ordinary men and women in eastern Pennsylvania truly believed that elections in 1863 and 1864 would determine the fate of the nation.

The transition of loyalty from the early portion of the war until its use in 1863 and 1864 should again push us to understand the complicated nature of loyalty. It was an organic construct, not something merely defined as the historical community has tried to do, with one party as loyal and the other less so. Democrats and Republicans equally implemented the concept of loyalty as a derisive concept throughout the third and fourth years of the war. Eastern Pennsylvanians became so embittered, so divided over the perceptions of loyalty that they drifted apart socially in some instances, and especially politically. Their conceptions of loyalty remained central to this process of division as well as the depiction of the political elections as crucial 
moments in the conduct of the Civil War. Divisions amongst the men and women of eastern Pennsylvania became dangerous in 1863 and 1864 because they came to see loyalty as the defining element of whether a person stood to save or destroy the Union. 


\section{Conclusion}

\section{Anxiety Vanished?}

In the months that followed the 1864 Presidential Election, the Civil War entered another, final stage. Much like the preceding years, when the elections passed, the discourse of loyalty amongst eastern Pennsylvanians faded from the headlines, replaced by discussions of the war and the occasional interjection of party rhetoric. However, unlike the struggle's first four years, the discourse of loyalty failed to reach the same antagonistic fervor it had before in the spring of 1865. Lincoln's electoral victory and the Northern military victory a few months later ended the crisis, the possibility that the election of the 'wrong' party would spell disaster for the nation. Of course, contemporary individuals did not know when the war would end, but Lincoln's electoral victory brought in a renewed vigor to the Union war effort. ${ }^{169}$ Victory was near at hand. Grant and Petersburg, Sherman and the sea, these events, the last months of fighting came to dominate the columns of local newspapers and grabbed the attention of eastern Pennsylvania soldiers and civilians, replacing the bitter discussion of politicized loyalty.

After Robert E. Lee surrendered at Appomattox Court House on April 9, 1865, the war was all but over. Eastern Pennsylvanians rallied together, across the political divide, to rejoice "a glorious day in the history of this nation...the day of triumph." ${ }^{170}$ Democrats and Republicans equally shared a relief that the war was over. ${ }^{171}$ That joyous outpouring however was short lived, as six days later Abraham Lincoln died in a bed too small for his towering frame, across the street from Ford's Theater, struck down by John Wilkes Booth. In the wake of Lincoln's assassination, eastern Pennsylvanians, humbled and grieving, banded together again at least

\footnotetext{
${ }^{169}$ Weber, Copperheads, 190-200.

${ }^{170}$ Northampton County Journal, April 12, 1865.

${ }^{171}$ Bucks County Intelligencer, April 11, 1865; Easton Free Press, April 6, 13, 1865; Easton Sentinel, April 13, 1865; Northampton County Journal, April 12, 1865; Reading Gazette and Democrat, April 8, $15,1865$.
} 
temporarily, in support of their fallen Chief Executive. Despite the years of rancor, division, and condemnation of one another about the issue of loyalty, Democrats and Republicans both praised Lincoln. For the country, his death was "a terrible tragedy" and "fell like a thunder clap" across the nation, Daniel Neiman from the Easton Sentinel reported. ${ }^{172}$ They felt, "At a time like this, political differences sink into nothingness, and every heart that is not dead to...feelings of humanity, beats in unison with abhorrence of the dastardly act." ${ }^{173}$ Collectively the residents of Berks, Bucks, Lehigh, and Northampton put aside their political differences and mourned for the murder of their President, praising him for ending the war and setting the nation on a path to peaceful restoration. ${ }^{174}$ Amidst their grief, eastern Pennsylvanians turned their attention to the hunt for Lincoln's killer, the subsequent trials of Booth's associates, as well as the search for exConfederate President Jefferson Davis. Local editors turned their attention to these topics, wresting control away from the issue of loyalty in the following months.

That spring, amongst the turmoil of the war's final days, local elections passed with little fanfare from the regional editors. No one discussed political loyalty or offered the traditional political banter that dominated headlines for so long during the Civil War. Between the end of March and the early parts of May, the use of loyalty all but disappeared from discussion in the region. After four years of bloody warfare that killed upwards of 750,000 men, cost billions of dollars, and remade the American nation, life began to return to normal for local residents. Newspaper editors focused their attention to local events, European affairs, and farming. Soldiers returned from the Union Army, families reunited, and the horror of battle passed into memory. The anxiety of four years of civil war seemed to have disappeared, along with the bitter

\footnotetext{
${ }^{172}$ Easton, Sentinel, April 20, 1865.

${ }^{173}$ Reading Gazette and Democrat, April 22, 1865.

${ }^{174}$ Bucks County Intelligencer, April 18, 1865; Easton Free Press, April 20, 1865; Easton, Sentinel, April 20, 1865; Henry Hornbeck, Diary, April 18, 1865; Northampton County Journal, April 19, 1865; Reading Gazette and Democrat, April 22, 29, 1865.
} 
contention that dominated the political arena that also appeared to have slunk underneath the outpouring joy that accompanied the arrival of peace. Despite the enthusiasm Democrats and Republicans expressed in the war's conclusion, the scars of the war remained far from healed. In fact, as spring gave way to summer, the return of electoral contests tore asunder any healing made towards the wounds suffered from the derisive nature of Civil War loyalty. Much like the wartime calendar that witnessed the ebb and flow of discourse over loyalty in regional papers, the return of the political campaign season returned partisan animosity to the newspapers and streets of eastern Pennsylvania.

The summer of 1865 saw the return of what we could politics as usual, but the pervasive issue of wartime loyalty made it difficult for eastern Pennsylvanians to return to a strictly normal sense of antebellum politics. Although local residents marginalized the issue of loyalty at the conclusion of the war and in its immediate aftermath, they dragged it back out again in the middle of 1865 . Editors from both parties quickly returned to their 1864 form, recalling the memory of wartime loyalty to influence the fall elections. The stakes for the nation were no longer as high as they had been for eastern Pennsylvanians in the crisis that dominated the last two years of the war. Such a distinction in severity however did not alter the ways in which editors interjected loyalty back into the political discourse. Wartime nicknames remained a common practice. Democrats still viewed their Republican adversaries as Abolitionists who upset the racial order, while Republicans conversely maintained the Copperhead nickname. ${ }^{175}$ The use of these nicknames, starting as early as May 1865, but reaching a more frequent appearance in late August and September, reveal that editors reincorporated the language of

\footnotetext{
${ }^{175}$ Use of Abolitionist: Easton Argus, August 24, September 7, 14, October 5 Easton Sentinel, June 8, 29, July 13, August 3, 1865; Reading Gazette and Democrat, September 2, 9, 1865. Use of Copperhead: Bucks County Intelligencer, September 26, 1865; Easton Free Press, May 4, August 8, September 14, 21, 28, 1865; Northampton County Journal, June 28, July 5, 12, 26, August 23, September 6, 13, 27, October 4, 1865.
} 
loyalty back into the local political debate. With the return of the Copperhead and Abolitionist labels, we can glean several important aspects of the immediate post-Civil War political discourse. First, editors used similar forms of rhetoric as they did during the war, offering characterizations of loyalty or disloyalty. Second, we see that the memory of loyalty quickly took root in the political dialogue of the postbellum period. Eastern Pennsylvanians had engrained the language of loyalty into their political rhetoric.

However, the use of loyalty returned in more than just the nicknames supplied by editors to classify their opponents as disloyal. Their resurrection of loyalty revived the notion that one party had been loyal during the war, while the other had not. Democrats, as their use of the Abolitionist label suggests, heavily focused on the issue of race. "If you are in favor of negro equality" or "going up to the ballot box by the side a wooly-headed negro" or are "in favor of admitting the negro into your family circle...vote the Abolition ticket" but if local men were in favor of sustaining "the Constitution, the Union and the cause of the white man" they were encouraged to vote for the Democratic ticket. ${ }^{176}$ The intention was to articulate that Republicans had betrayed the nation and its principles by subverting the racial hierarchy. Democrats did not always argue in racial terms, as we can see when they urged their constituents to support a party that "never abused or betrayed" the Constitution, power, or the people. ${ }^{177}$ But through both examples, Democratic editors conjured the notion that Republicans acted disloyally during the Civil War. Abolitionists opposed the established racial order, ordained by the Constitution, and were deliberately disloyal to the principles of the American nation. Electing Democratic candidates would "vindicate" and help correct the course of the nation, essentially righting the

\footnotetext{
${ }^{176}$ Easton Argus, 6, 1865.

${ }^{177}$ Reading Gazette and Democrat, July 22, 1865.
} 
wrongs of the war years. ${ }^{178}$ Republican editors sidestepped the racial issue and focused heavily on the perceived disloyalty of Democrats during the Civil War. Copperheads had a "record of hostility...to a vigorous and successful prosecution of the war against treason," which along with their "want of sympathy for the Union Soldier," completely proved "the disloyalty of the Copperhead party." ${ }^{179}$ In the summer and fall of 1865, Republicans called on the fact that Democrats opposed many of their wartime measures (evidenced by constant Democratic attempts to subvert emancipation), thus reminding local residents of the perceived disloyalty of Republican opponents during the Civil War. Regardless of whether the arguments centered around the usage of race or hostility to Lincoln's conduct during the war, after a brief period of relaxed anxieties over the issue of loyalty, local editors revived such discussions in full force for the political campaigns of 1865 in eastern Pennsylvania. ${ }^{180}$

The reemergence of the rhetoric of loyalty, although on a less grand scale, is a good place to reflect on the meaning of that concept for eastern Pennsylvanians both during and after the Civil War. Even with the assassination of Abraham Lincoln, the return of local soldiers, and the joy of the conflict's termination, regional residents could not shake the legacy of loyalty. Four years of bitter, antagonistic rhetoric left deep divisions amongst the people of Berks, Bucks, Lehigh, and Northampton counties. Members of both parties during the war saw their political organization as the only entity capable of rescuing the nation. Historiographically, this antagonistic use of loyalty amongst individuals like James Peifer, Beates Swift, Thomas Jackson, Mary Hornbeck, and the local newspaper editors alert us to the inadequacies of how previous

\footnotetext{
${ }^{178}$ Reading Gazette and Democrat, July 22, 1865.

${ }^{179}$ Northampton County Journal, September 27, 1865.

${ }^{180}$ Bucks County Intelligencer, April 25, May 9, July 18, September 26, October 17, 1865; Easton Free Press, May 4, 11, July 27, September 28, 1865; Easton, Sentinel, June 29, August 17, August 24; Northampton County Journal, August 23, 1865, September 13, 27, 1865; Reading Gazette and Democrat, May 13, July 22, August 26, October 14, 1865 .
} 
historians have framed investigations of Civil War era loyalty. Instead of inquiring as to who was loyal, my examination explored the concept of loyalty and its meaning to ordinary men and women. Likewise, the reemergence of loyalty after the war's conclusion highlights the importance of loyalty as a factor in eastern Pennsylvanians daily lives. It not only affected the contours of the war, but it hardened the political divide of the region. The first post-war elections highlight how much conceptions of loyalty divided eastern Pennsylvania during and after the war.

Of course, loyalty was not the only concept that influenced their wartime experience, everything from class to race to gender (among a great many others) played a part as well. But those concepts, while important, have received a great deal of attention from the historical community already. Loyalty as lens of analysis, on the other hand, has not received nearly enough. Historians have discussed who was loyal, but not how ordinary people used loyalty. My examination of loyalty as a cultural concept revealed that depictions of loyalty not only affected the political realm, but also manifested itself amongst social relations, views on the war, and consequently generated a crisis for American democracy.

The scope of this project remained limited in order to understanding how loyalty worked on a personal scale in one divided region of the country. How did it work outside the boundaries of this region? Eastern Pennsylvania, while based in agricultural pursuits, with a mixture of urban and rural settings, cannot represent the whole North, nor the rest of the Keystone. There is a pressing need to understand how Americans, in an expanded geographic and chronological frame understood and used loyalty. Did the Midwest, a hotbed for anti-war sentiment, and arguably the birthplace of Copperheadism differ from Eastern Pennsylvania in regards to loyalty? What about New England and other staunchly Republican localities? How did border 
states, such as Maryland or Missouri, occupied in some instances by Federal Forces and as the battleground for many of the war's engagements fit into the picture? What about West Virginia, a place that to show its displeasure with secession seceded from Virginia? Additionally, as the post-war experiences of 1865 indicate, loyalty remained a significant aspect of the post-war political culture. Historiographically, the trend is to highlight how Republicans waved the "bloody shirt" - critiquing Democrats for wartime disloyalty. ${ }^{181}$ My brief foray into the post-war world shows this was the practice almost from the outset. Yet I should also stress that Democrats waved a "black shirt" that attacked Republicans on the issue of race and emancipation. Despite a brief reprieve, politicians and their supporters in eastern Pennsylvania easily turned towards "shirt" waving, accusing their opponents of wartime disloyalty to aid their postwar electoral chances. Therefore, in future studies of loyalty we should also ask how Americans used loyalty in the post-war years of Reconstruction? When and how did the wartime conceptions of loyalty die out? Did they?

Historians need to continue parsing the importance, effects, and conceptions of loyalty on the Northern populace during the Civil War. After all, the depictions of political parties as Copperheads and Blacksnakes embedded the conceptions of loyalty into an either-or paradigm. The election of one party, one definition of loyalty, as depicted by eastern Pennsylvanians, offered the prospects of successful reunification and Union victory, while the political opposition presented despair, turmoil, and division of the nation. Eastern Pennsylvanians deployed loyalty as means to understand politics and daily life during the Civil War; it drove how they conceptualized the conflict and the people around them. "All anxiety for the future...vanished"

\footnotetext{
${ }^{181}$ Sandow, Deserter Country, 141-2.
} 
with the conclusion of the war, but the divisive nature of loyalty, ever present during the war, remained deeply etched into the hearts of eastern Pennsylvania's men and women. ${ }^{182}$

${ }^{182}$ Northampton County Journal, June 12, 1865. 


\section{Bibliography}

Primary Sources

Manuscripts:

Boone, Samuel G., Letters. 1863-37, Civil War Letters. Historic Society of Berks County, Reading, Pennsylvania.

Camard, Geo. Letter to Friend Lew, April 25, 1863. Historic Society of Berks County, Reading, Pennsylvania.

Civil War Papers (Lists or enrollments into the Army Bucks County). Civil War Collection, 1861-1865. Bucks County Historical Society, Doylestown, Pennsylvania.

Correspondence, 153d. Regiment, Penna. Volunteer Infantry, 1862-1863. Easton Public Library, Marx Room, Easton, Pennsylvania.

Dillinger, John P. Letter to Mary Samuels and Emma Knauss, November 20, 1862. Lehigh Valley Heritage Museum, Allentown, Pennsylvania.

Fell, Newlin. Letter to Mother, September 28, 1862. Bucks County Historical Society, Doylestown, Pennsylvania.

Hibbs Family Records, 1817-1960. Bucks County Historical Society, Doylestown, Pennsylvania.

Hornbeck, Henry Jacob. Diary of Civil War Service by Henry Jacob Hornbeck September 1862June 1864. Lehigh Valley Heritage Museum, Allentown, PA.

Howell, Theodore., Letters, 1862-1863. Lehigh Valley Heritage Museum, Allentown, PA.

Jackson, Thomas., Letters, 1862-1874. Historic Society of Berks County, Reading, Pennsylvania.

Kemp, Joseph N., Letters. Shanaman Collection. Historic Society of Berks County, Reading, Pennsylvania.

Melick, Philip W. Diary of Rev. Philip W. Melick, Chaplain, 153d Regiment, Pennsylvania Volunteer Infantry, 1862-63. Easton Public Library, Marx Room.

Mickley, Charles. Letter to Chas. S. Bush Esq, October 21, 1862. Lehigh Valley Heritage Museum, Allentown, PA.

Paxson Family Collection, 1825-1955. Bucks County Historical Society, Doylestown, Pennsylvania.

Rhoads, John H., Letters. 1863-11, Civil War Letters. Historic Society of Berks County, Reading, Pennsylvania.

Richards, Louis. Diary of the Militia Companies of 1862 and 1863. MIC 363. Historic Society of Berks County, Reading, Pennsylvania. 
Stofflet, Francis. Diary of Francis Stofflet: Private Co. D. 153d. Pa. Vols. 1862-63. Easton Public Library, Marx Room.

Wallace, Stryker A. Diary of Stryker A. Wallace, Private, Co. G. 153d Pa. Vols., 1862-63. Easton Public Library, Marx Room.

Printed Sources:

Frueauff, John Frederick. Freddy's War: The Civil War Letters of John Frederick Frueauff. Edited by Gilbert, Daniel. Bethlehem, Pa: Moravian College, 2006.

Peifer, James A. Bethlehem Boy: The Civil War Letters \& Diary of James A. Peifer. Eds. Carolyn W. Able and Patricia N. McAndrew. Bethlehem, PA: Moon Trail Books, 2007.

Reichard, William J. The Civil War Letters of William J. Reichard, 1862-1863. In Proceedings of the Lehigh County Historical Society, Vol. 22, edited by William J. Wilcon, Esq., 136280. Allentown, Pa: Lehigh County Historical Society, 1958.

Swift, Beates Robeson. The 1863 Diary of Beates R. Swift: A Year in the Life of an Easton Youth During the Civil War. Ed. Ned D. Heindel. Easton, PA: Northampton County Historical \& Genealogical Society, 2004.

Newspapers:

Berks \& Schuylkill Journal

The Bucks County Intelligencer

Doylestown Democrat

Easton Argus

Easton Free Press

Easton Sentinel

Northampton County Journal

Reading Gazette and Democrat

Secondary Sources

Books:

Anderson, Benedict. Imagined Communities: Reflections on the Origin and Spread of Nationalism. London: Vesro, 1983.

Ayers, Edward. In the Presence of Mine Enemies: War in the Heart of America, 1859-1863. New York: W.W. Norton, 2003. 
Baker, Jean H. Affairs of Party: The Political Culture of Northern Democrats in the MidNineteenth Century. Ithaca, NY: Cornell University Press, 1983.

Dell, Christopher. Lincoln and the War Democrats: The Grand Erosion of Conservative Tradition. Cranbury, New Jersey: Associated University Press, 1975.

Dorsey, Bruce. Reforming Men \& Women: Gender in the Antebellum City. Ithaca: Cornell University Press, 2002.

Engle, Stephen. All the President's Statesmen: Northern Governors and the American Civil War. Milwaukee: Marquette University Press, 2006.

Fabian, Anne. The Skull Collectors: Race, Science, and America's Unburied Dead. Chicago: University of Chicago Press, 2010.

Foner, Eric. Free Soil, Free Labor, Free Men: The Ideology of the Republican Party Before the Civil War. Oxford: Oxford University Press, 1995.

Formisano, Ronald P. For the People: American Populist Movements from the Revolution to the 1850s. Chapel Hill: University of North Carolina Press, 2008.

Formisano, Ronald. The Transformation of Political Culture: Massachusetts Parties, 1790s1840s. New York: Oxford University Press, 1983.

Frank, Joseph Allan. With Ballot and Bayonet: The Political Socialization of America Civil War Soldiers. Athens: University of George Press, 1998.

Gallagher, Gary. The Union War. Cambridge: Harvard University Press, 2011.

Gallman, J. Matthew. Mastering Wartime: A Social History of Philadelphia During the Civil War. Philadelphia: University of Philadelphia Press, 1990.

Gallman, J. Matthew. The North Fights the Civil War: The Home Front. Chicago: Ivan R. Dee, 1994.

Grant, Susan-Mary. North Over South: Northern Nationalism and American Identity in the Antebellum Era. Lawrence: University Press of Kansas, 2000.

Guelzo, Allen C. Fateful Lightning: A New History of the Civil War and Reconstruction. New York: Oxford University Press, 2012.

Harris, Leslie M. In the Shadow of Slavery: African Americans in New York City, 1626-1863. Chicago: University of Chicago Press, 2003.

Hess, Earl J. Liberty, Virtue, and Progress: Northerners and Their War for Union. Second Edition. New York: Fordham University Press, 1997.

Howe, Daniel Walker. What Hath God Wrought: The Transformation of American, 1815-1848. Oxford: Oxford University Press, 2007. 
Jacoby, Karl. Shadows at Dawn: An Apache Massacre and the Violence of History. New York: Penguin Books, 2008.

Jaffee, David. A Nation of New Goods: The Material Culture of Early America. Philadelphia: University of Pennsylvania Press, 2010.

Kantrowitz, Stephen. More Than Freedom Fighting for Black Citizenship in a White Republic, 1829-1889. New York: The Penguin Press, 2012.

Klement, Frank L. The Copperheads in the Middle West. Chicago: The University of Chicago Press, 1960.

Klement, Frank L. Dark Lanterns: Secret Political Societies, Conspiracies, and Treason Trials in the Civil War. Baton Rouge: Louisiana State University Press, 1984.

Knupfer, Peter B. The Union As it Is: Constitutional Unionism and Sectional Compromise, 17871861. Chapel Hill: University of North Carolina Press, 1991.

Lawson, Melinda. Patriot Fires: Forging a New American Nationalism in the Civil War North. Lawrence, Kansas: University of Kansas Press, 2002.

Manning, Chandra. What This Cruel War Was Over: Soldiers, Slavery, and the Civil War. New York: Vintage Books, 2007.

Majewski, John. A House Dividing: Economic Development in Pennsylvania and Virginia Before the Civil War. Cambridge: Cambridge University Press, 2000.

McPherson, James. Battle Cry of Freedom: The Civil War Era. New York: Oxford University Press, 1988.

McPherson, James. For Cause and Comrades: Why Men Fought in the Civil War. New York: Oxford University Press, 1997.

Mitchell, Reid. Civil War Soldiers: Their Expectations and Their Experiences. New York: Viking, 1988.

Mitchell, Reid. The Vacant Chair: The Northern Soldier Leaves Home. New York: Oxford University Press, 1993.

Neely Jr., Mark E. The Boundaries of American Political Culture in the Civil War Era. Chapel Hill: The University of North Carolina Press, 2005.

Neely Jr. Mark E. The Fate of Liberty: Abraham Lincoln and Civil Liberties. New York: Oxford University Press, 1991.

Neely Jr., Mark E. Lincoln and the Triumph of the Nation: Constitutional Conflict in the American Civil War. Chapel Hill: UNC Press, 2011.

Neely Jr., Mark E. The Union Divided: Party Conflict in the Civil War North. Cambridge: Harvard University Press, 2002. 
Nelson, Scott and Carol Sheriff. A People at War: Civilians and Soldiers in America's Civil War, 1854-1877. New York: Oxford University Press, 2008.

Palladino, Grace. Another Civil War: Labor, Capital, and the State in the Anthracite Regions of Pennsylvania, 1840-1868. Urbana: University of Illinois Press, 1990.

Paludan, Phillip Shaw. A People's Contest: The Union \& Civil War, 1861-1865 $2^{\text {nd }}$ Edition. Lawrence, Kansas: University of Kansas, 1996.

Sandow, Robert M. Deserter Country: Civil War Opposition in the Pennsylvania Appalachians. New York: Fordham University Press, 2009.

Shankman, Arnold. The Pennsylvania Antiwar Movement, 1861-1865. Rutherford, NJ: Farleigh Dickinson University Press, 1980.

Smith, Adam I. P. No Party Now: Politics in the Civil War North. Oxford: Oxford University Press, 2006.

Valuska, David L. and Christian Keller. Damn Dutch: Pennsylvania Germans at Gettysburg. Mechanicsburg, PA: Stackpole Books, 2010.

Varon, Elizabeth. Disunion!: The Coming of the American Civil War, 1789-1859. Chapel Hill: The University of North Carolina Press, 2008.

Waldstreicher, David. In The Midst of Perpetual Fetes: The Making of American Nationalism, 1776-1820. Chapel Hill: University of North Carolina Press, 1997.

Weber, Jennifer. Copperheads: The Rise and Fall of Lincoln's Opponents in the North. Oxford: Oxford University Press, 2006.

Yokota, Kariann Akemi. Unbecoming British: How Revolutionary America Became a Postcolonial Nation. Oxford: Oxford University Press, 2011.

Articles and Book Chapters:

Blair, William. "We are Coming, Father Abraham, Eventually : The Problem of Northern Nationalism in the Pennsylvania Recruiting Drives of 1862." In The War was You and Me: Civilians in the American Civil War, edited by Joan Cashin. Princeton: Princeton University Press, 2002.

Johnson, Russell. “"Volunteer While You May": Manpower Mobilization in Dubuque, Iowa." in Union Soldiers and the Northern Home Front: Wartime Experience, Postwar Adjustments. edited by Cimbala, Paul A. and Randall Miller, New York; Fordham University Press, 2002.

Hofstadter, Richard. "The Paranoid Style in American Politics.” Harper's Magazine. November 1964.

McKitrick, Eric. "Party Politics and the Union and Confederate War Efforts." In The American Party System: Stages of Development. Edited by William Nisbet Chambers and Walter Dean Burnham. New York: Oxford University Press, 1967. 
Nalty, Sean. "“CCome Weal, Come Woe, I am with the Anti-Slavery Party”: Federalism and the Formation of the Pennsylvania Union Party 1860-1864." In A Political Nation: New Directions in Mid-Nineteenth-Century American Political History, Edited by Gary W. Gallagher and Rachel A. Shelden. Charlottesville, VA: University of Virginia Press, 2012.

Neely, Mark E. "Apotheosis of a Ruffian: The Murder of Bill Pool and American Political Culture." In A Political Nation: New Directions in Mid-Nineteenth-Century American Political History, Edited by Gary W. Gallagher and Rachel A. Shelden. Charlottesville, VA: University of Virginia Press, 2012.

Orr, Timothy J. “"A Viler Enemy in Our Rear': Pennsylvania Soldiers Confront the North’s Anti-War Movement." In The View from the Ground: Experience of Civil War Soldiers. Edited by Aaron Charles Sheehan-Dean, Lexington, KY: University Press of Kentucky, 2007.

Pasley, Jeffrey L. ““'The Cheese and the Words: Popular Political Culture and Participatory Democracy in the Early American Republic." In Beyond the Founders: New Approaches to the Political History of the Early American Republic. Edited by Jeffrey L. Pasley, Andrew W. Robertson, and David Waldstreicher. Chapel Hill: University of North Carolina Press, 2004.

Reardon, Carol. "'We are all in this war': the 148th Pennsylvania and home front dissension in Centre County during the Civil War." In Union Soldiers and the Northern Home Front: Wartime Experience, Postwar Adjustments. Edited by Cimbala, Paul A. and Randall Miller. New York: Fordham University Press, 2002.

Snell, Mark A. " "If they would know what I know it would be pretty hard to raise one company in York': Recruiting, the Draft, and Society's Response in York County, Pennsylvania." in Union Soldiers and the Northern Home Front: Wartime Experience, Postwar Adjustments. edited by Cimbala, Paul A. and Randall Miller, New York; Fordham University Press, 2002. 